University of Louisville

ThinkIR: The University of Louisville's Institutional Repository

Electronic Theses and Dissertations

1940

\title{
A comparison of various sizes of inverted vials used in Durham fermentation tubes.
}

Blanche Mae Welsh

University of Louisville

Follow this and additional works at: https://ir.library.louisville.edu/etd

Part of the Bacteriology Commons

\section{Recommended Citation}

Welsh, Blanche Mae, "A comparison of various sizes of inverted vials used in Durham fermentation tubes." (1940). Electronic Theses and Dissertations. Paper 1941.

https://doi.org/10.18297/etd/1941

This Master's Thesis is brought to you for free and open access by ThinkIR: The University of Louisville's Institutional Repository. It has been accepted for inclusion in Electronic Theses and Dissertations by an authorized administrator of ThinkIR: The University of Louisville's Institutional Repository. This title appears here courtesy of the author, who has retained all other copyrights. For more information, please contact thinkir@louisville.edu. 


\title{
A COMPARIS ON OF VARIOUS SIZES OF INVERTED VIAIS \\ USED IIN DURHAN FERNANTAT ION TUBES
}

\author{
A Dissertation \\ Submitted to the Faculty \\ of the Graduate School of the University of Louisville \\ in Partial Fulfillment of the \\ Requirements for the Degree \\ of Master of science
}

Department of Bacteriology

by

Blanche liae Welsh

Year

1940 
IAIE OF STD ZIT: Blanche rae reish

TIL OF LTESIS: A Companis on of Vojous Sizes of

Inverted Viels Usod in Durham

Fermentation Tubes

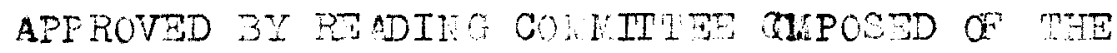

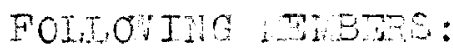

NAIG OF DIRECTOR:

D.int Bnay 23,1940 


\section{ACKNOWLEDGEMENT}

I am indebted to the helpful criticism and valuable suggestions of Dr.J.A. Kennedy whose direction has made this paper possible. 
Prege 10 .

I Introduction 1

I Review of the titerature 7

III detomials and lethods II

IV obsenvations and jiscussion I4

A. Charts in lilizireters

B. Charts in Fercentoges

a. Discuszion of Chents

D. Chant of Averares

I. Diccusaton of Averges

$V \quad$ Summary and Conclusions 46

VI References 48 
INTRODUCT ION 
Bacteriologists have clasgified bacteria with the ald of various culture media. They have studied the physiological and chemical reactions of the micro-organisms on these media. For example, some micro-organisms decompose carbohydrate broth to produce acid and gas; others are unable to do this. Some bacteria act upon protein, digesting and liquifying it, and others are incapable of breaking down proteins. Some micro-organisms may produce a fat splitting enzyme, and some may reduce nitrates to nitrites. "The use of a relatively small series of fermentation tests, including especially dextrose, lactose, sucrose, starch and inulin, action on litmus milk, and indole formation resulted in the recognition of certain primary divisions within this group (Refik 1896, Grimbert and Legros 1900, Durham 1901, Jordon 1903." *

In order to determine whether or not bacteria produce acid and gas in carbohydrate media an apparatus for collection of gas, if produced, must be used -- the so-called fermentation tube.

Theobald Smith, who first clearly showed the value of comparative fermentation of the various sugars in identifying and differentiating bacteria, was the first, it would seem, to use a fermentation tube in bacteriology. He employed a tube which was U-shaped to show gas production in his experiments. This tube, which bears his name, has been generally accepted in scientific studies. In his paper, "The Fermentation Tube" and Immunology, 2nd edition, $1936, \frac{p}{p} .520$. 
which appeared in the Wlider Quarter Century Book, Smith states that he found the fermentation tube to be an apparatus of considerable antiquity and of uncertain origin; in Detmer's pflanzenphysiologisches practicum it figured as Kuhne'scher G'dhrungsgefass. It has been more recently utilized by Einhorn for the quantitative determination of sugar in urine and by Doremus for the estimation of urea. But the first application in bacteriology was made by Smith in 1889 for the purpose of securing anaerobiosis, and in several publications (Centralblatt fur Bakteriologie, 1890, VIII, S 389; J. Boston Society of Medical Science, 1899, III, p. 340) he emphasized its fundamental usefulness for the detection of gas formed by bacteria in media containing carbohydrates. The tube devised by Smith was suitable for experimental purposes, which were not too extensive, but when used in large numbers, was found to be expensive due to ease of breaking, its initial cost, difficulty of cleaning, tediousness to work with because of difficulty of filling, and because of the special racks required to hold the tubes.

A distinct advance from the viewpoint of cheapness, ease of manipulation, and freedom from breakage was made when Herbert Durham proposed and later successfully applied in his studies of the colon-typhold-dysentery group the tube which he describes in his paper: "A Simple Method for Demonstrating the Production of Gas by Bacteria." In this paper he gave a description of 
the tube which consisted of an inverted vial placed in a larger test tube. No size for either tube was specified; the only requirement being that the inverted vial must be movable when placed in the larger tube. The media was placed in the larger tube containing the inverted vial and sterilized. The liquid entered the inverted vial after the first or second sterilization. The inoculant was added to the medium, dispersed between the large and the small tube, and after proper incubation, if the organisms were gas formers, gas would be produced in the upper region of the inverted vial.

The Durham tube is now used extensively in sanitary bacteriology and in diagnostic bacterlology. The colonparatyphoid-typhoid-dysentery groups are so much alike in cultural characteristics that special diagnostic procedures involving inoculation of various kinds of special culture media are necessary in order to determine their exact identity. The five "sugar" media commonly used are dextrose, lactose, mannitol, sucrose, and xylose broth. Carbohydrate media are used to determine whether or not the bacteria under consideration can decompose the particular sugar with production of acid and gas or acid alone. To detect the production of acid, a dye such as brom-cresol-purple is added to the original culture media. In addition to the carbohydrate media,tryptone for indole production and brom-cresol-purple milk are utilized. In the following chart are given the differential characteristics of the enteric micro-organisms. 
Biochemical Oharacteristics of the colon-paratyphoid-typhoid-dysentery Group

\begin{tabular}{|c|c|c|c|c|c|c|c|c|c|c|}
\hline$\frac{\text { Organism }}{\text { Bacterium }}$ & $\begin{array}{l}\text { Motil- } \\
\text { Ity }\end{array}$ & $\begin{array}{l}\text { Russ } \\
\text { Slant }\end{array}$ & $\begin{array}{l}1 \text { 's } \\
\text { Butt }\end{array}$ & $\begin{array}{c}\text { Dex- } \\
\text { trose }\end{array}$ & $\begin{array}{l}\text { Lac- } \\
\text { tose }\end{array}$ & $\begin{array}{c}\text { Sucr= } \\
\text { ose }\end{array}$ & $\begin{array}{l}\text { Mann- } \\
\text { itol }\end{array}$ & $\begin{array}{l}\text { XyI- } \\
\text { ose }\end{array}$ & $\begin{array}{l}\text { BOP } \\
\text { Mi11 }\end{array}$ & $\begin{array}{l}\text { Ind- } \\
\text { ole }\end{array}$ \\
\hline alkaligenes & + & - & - & - & - & - & - & - & - & - \\
\hline $\begin{array}{l}\text { aerogenes } \\
0011\left(\begin{array}{l}\text { lor } \\
\text { is }\end{array}\right) \\
\text { coli }\end{array}$ & $\overrightarrow{+}$ & $\begin{array}{l}\mathbf{A} \\
\mathbf{A} \\
\mathbf{A}\end{array}$ & $\begin{array}{l}A G \\
A G \\
A G\end{array}$ & $\begin{array}{l}\text { AG } \\
A G \\
A G\end{array}$ & $\begin{array}{l}\mathrm{AG} \\
\mathrm{AG} \\
\mathrm{AG}\end{array}$ & $\begin{array}{l}\text { AG } \\
A G \\
-\end{array}$ & $\begin{array}{l}\text { AG } \\
A G \\
A G\end{array}$ & & $\begin{array}{l}\text { A } \\
\text { A } \\
\text { A }\end{array}$ & $\dot{+}$ \\
\hline $\begin{array}{l}\text { paratyphosum B } \\
\text { paratyphosum A } \\
\text { Morgani \#I } \\
\text { Newoastle dys. * }\end{array}$ & $\begin{array}{l}+ \\
+ \\
+ \\
-\end{array}$ & $\bar{z}$ & $\begin{array}{l}A G \\
A G \\
A G \\
A G\end{array}$ & $\begin{array}{l}A G \\
A G \\
A G \\
A G\end{array}$ & $\begin{array}{l}= \\
= \\
=\end{array}$ & $\bar{z}$ & $\begin{array}{l}\text { AG } \\
\text { AG } \\
- \\
-\end{array}$ & $\begin{array}{l}\overline{A G} \\
\bar{?}\end{array}$ & $\underset{\substack{A-A 1 k \\
A \rightarrow A I k}}{\substack{A \\
A}}$ & $\overline{-}$ \\
\hline typhosum & + & $=$ & A & $\bar{A}$ & $=$ & $=$ & $\bar{A}$ & - orA & A & $=$ \\
\hline $\begin{array}{l}\text { dispar } \\
\text { Sonne }\end{array}$ & $\bar{z}$ & $\overline{-}$ & $\begin{array}{l}\mathbf{A} \\
\mathbf{A}\end{array}$ & $\begin{array}{l}\text { A } \\
\text { A }\end{array}$ & $\begin{array}{l}\text { A slon } \\
\text { A slon }\end{array}$ & $-\operatorname{orA}$ & $\begin{array}{l}\text { T } \\
\text { A }\end{array}$ & - & $\begin{array}{l}\text { A } \\
A\end{array}$ & $\stackrel{t}{-}$ \\
\hline $\begin{array}{l}\text { Flexner** } \\
\text { alkalesoens** } \\
\text { Shiga } \\
\text { para-shiga } \\
\text { Sohmitz }\end{array}$ & $\begin{array}{l}\bar{z} \\
\bar{z}\end{array}$ & $\begin{array}{l}= \\
= \\
=\end{array}$ & $\begin{array}{l}\text { A } \\
A \\
A \\
A \\
A\end{array}$ & $\begin{array}{l}\text { A } \\
\text { A } \\
\text { A } \\
\text { A } \\
\text { A }\end{array}$ & 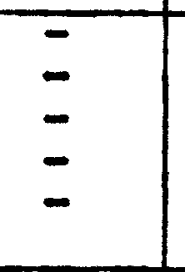 & $\begin{array}{c}- \\
- \\
- \\
-o r\end{array}$ & $\begin{array}{l}\text { E } \\
A \\
- \\
- \\
-\end{array}$ & $\begin{array}{l}\overline{\mathbf{A}} \\
\overline{-} \\
\overline{-}\end{array}$ & $\begin{array}{l}A \\
A 1 k \\
A \\
A-A \\
A\end{array}$ & $\begin{array}{l}+ \\
\pm \\
+\end{array}$ \\
\hline
\end{tabular}

*The Newoastle dysentery baollius ferments dulcitol slowly (3-9) days).

**Alkalescens ferments dulcitol; Flexner does not ferment duloitol.

Chart taken from Laboratory Hanual of Hedical Bacteriology and Immunology (1939-1940)

by J. A. Kennedy. (author's permission). 
In sanitary bacteriology the colon-aerogenes group is of extreme importance. Since water is subject to sewage contamination, the aim of the bacteriological analysis of a water is to find evidence of excretal pollution. Many pathogenic bacteria die soon after they reach water. The intestinal pathogens, e.g., typhoid bacilli, paratyphoid bacilli, and dysentery bacilil, may be transmitted by drinking water since they do survive for some time in water. The bacteriologist determines the presence or absence of the colon-aerogenes group. The presence of this group renders the water in question a potential source of infection from enteric pathogens and therefore nonpotable. The life of the typhoid bacillus and the cholera spirillum in water is comparatively short. Examination of water known to have transmitted or even to have been suspected of transmitting these pathogens is often so delayed that the pathogen1c micro-organisms, in the meantime, have perished. For these reasons the search for specific pathogenic bacteria is rarely crowned with success, and their real or apparent absence affords no good ground for judging the general safety of the water. The actual number of bacteria in water is also no absolute criterion of $1 \mathrm{ts}$ wholesomeness, although taken together with other factors concerning the source and history of the water, it may be helpful in forming an opinion. The test for the colon-aerogenes group is based upon the fact that these micro-organisms, and especially Bacterium col1, are common inhabitants of the intestinal tract and are found 
in great abundance in sewage. Their close blological relationship to the typhoid, paratyphoid, and dysentery bacilli, and the fact that, like the latter micro-organisms, they find their way into sewage chlefly from the discharges of the body renders their presence, especially when in large numbers, particularly suggestive. The test for micro-organisms of the colon-aerogenes group is almost univergally conceded to be the most significant determination in the bacteriological examination of water since it affords the most nearly specific test of fecal contamination. The formation of $10 \%$ or more of gas in the Durham tube containing lactose broth within 24 hours at $37^{\circ} \mathrm{C}$ is presumptive evidence of the presence of members of the group. Lactose broth is used since it eliminates many forms unrelated to the colon group. For example, many micro-organisms will ferment glucose that will not ferment lactose and which, consequently, do not belong to the colon-aerogenes group. 
- REVIEW OF LITERATURE 
William Browne published a paper on "A Comparative Study of the Relative Efficiencies of Certain Fermentation Tubes", in which he compared the Durham and the Smith fermentation tubes using the liquor from oysters. He found the inverted vial more efficient in low dilutions and the Smith tube more efficient in higher dilutions. His most important conclusion was that, due to irregularities in the amount of gas produced in the tubes and the failure of some of the tubes to show any gas production, it was imperative to use the tubes (either Smith or Durham) in duplicate or triplicate.

Later Lee and Fegely in "An Experimental Study on the Relative Efficlencies of Certain Fermentation Tubes" showed the Durham tube to be superior to the Smith tube. At the end of twenty-four hour incubation periods (if efficiency is based on the accuracy obtainable) there was no difference, while at the end of longer periods, efficiency in concentrated solutions favored the Durham tube and in dilute solutions favored the Smith tube. They also came to the conclusion that the most obvious result was irregularity as shown by figures given in their charts.

Ivan Hall, who modified the Durham tube, stated that the greatest objection to the original Durham tube was in the qualitative and quantitative determination of gas; likewise, it was futile in the Smith tube to measure the gas due to varying absorption of $\mathrm{CO}_{2}$ by the culture media. He sought to overcome the only fault of the Durham tube which would prevent it from 
being equal to Smith's. This fault was the irregular results obtained in higher dilutions (as stated in Browne's paper) because of the fact that there was insufficient communication between the inside and outside of the vial due to the square end of the latter which fitted snugly against the bottom of the larger test tube. In the case of non-motile or canisms a longer time would be required to reach inside of the inverted vial than to reach the upper part of the smith tube. Hall prepared a tube which had an opening at a forty-five degree angle, and by a series of experiments concluded that the diagonally cut vial is preferable due to the fact (1) that non-motile organisms could reach inside the vial, (2) that the amount of gas produced is greater, and (3) that the gas is in a larger number of tubes than in either the Smith or the square cut vial. These above factors were considered important in presumptive tests.

In 1917, Graves prepared another tube. His objection to the Hall and Durham tubes was that you had to shake the media sufficiently to get germs into the inner tube which was not heavily inoculated. He found that shaking the tube produced gas in some tubes, while others remained gasless. In comparison with the unshaken tubes, the shaken tubes had a greater percentage of gas. Also he stated that a false negative might be given because the germs could be held near the surface of the medium by surface tension. His inner tube was a vial (30 $\mathrm{mm} \times 5 \mathrm{~mm}$ ) inverted over a wooden $\operatorname{rod}(50 \mathrm{~mm} \times 2 \mathrm{~mm}$ ) in 
a test tube $(20 \mathrm{~mm} \times 250 \mathrm{~mm})$ containing $20 \mathrm{cc}$ of media. This allowed free circulation of the medium, and shaking was more thoroughly accomplished because the rod aided in churning and in drawing and expeling the medium. By raising the mouth of the vial, a certain amount of gas, which is formed between the mouth of the inverted vial and the bottom of the larger tube, was thereby entrapped.

Nelther the Hall nor the Graves modification of the Durham tube has replaced the original tube, which is now used extensively both in sanitary bacterlology and in diagnostic bacteriology.

In some laboratory supply catalogues the combination of the inverted tube in the larger tube is referred to as the "Dunham". The Arthur H. Thomas Company advertises the tube as a "Durham tube", but, in answer to my inquiry, they write that they "have never been quite sure that the late Dr. E. K. Dunham, of New York, did not devise or use a similar arrangement of tubes because the name "Dunham" was used in connection with it in the Laboratory Apparatus trade for a number of years". After searching the Index Medicus and Quarterly Cumulative Index, I have found no reference to Dr. Dunham in connection with this special tube. In response to my letters, the other companies who advertised the tube as "Dunham" did not give a reason for the use of this name.

Various catalogues also refer to standard and regular size Durham fermentation tubes approved by the American Public Health Association. In reply to my letter about specifications 
for the Durham tube, the American Public Health Association answered that no reference to various sizes was given by them, and they concluded that the size had been found to be of little importance because no specified size is included in the directions for performing the test in the "standard Methods for the Examination of Water". 
MATERIALS AND IETHODS 
The aim of this paper was to determine the most efficient size of inverted vial used in the Durham fermentation tube. A series of fermentation experiments was run on seven sizes of inverted vials. The sizes employed were $9 \mathrm{~mm} \times 40 \mathrm{~mm}$ (flat top), $7 \mathrm{~mm} \times 40 \mathrm{~mm}$ (flat top), $5 \mathrm{~mm} \times 60 \mathrm{~mm}, 5 \mathrm{~mm} \times 40 \mathrm{~mm}, 5 \mathrm{~mm} \times$ $30 \mathrm{~mm}, 9 \mathrm{~mm} \times 76 \mathrm{~mm}$, and $7 \mathrm{~mm} \times 45 \mathrm{~mm}$ (all five round top). The outer tube measured $184 \mathrm{~mm} \times 18 \mathrm{~mm}$; in all cases the medium used was lactose broth, and the inoculum was Bacterium coli, our strain \#71.

The procedure in this experiment was based on the reguirements specified for water analysis by the American Public Health Association in its publication Standard Methods for the Examination of Water and Sewage, eighth edition, 1936.

In Standard Methods for the Examination of Water and Sewage it states that ny type of fermentation tube may be used provided It allows conformance to the requirement for concentration of nutritive ingredients, which are that lactose broth, prepared according to the directions given (Part VII, Section III E), contains amounts $(0.5 \%)$ of peptone and lactose which yields an optimum growth of the organisms of the coli-aerogenes group, and twice as much medium as water to be tested must be used.

The ingredients used in the lactose broth are:

$\begin{array}{lc}\text { Distilled water } & 1 \mathrm{~kg} \\ \text { Beef extract } & 3 \text { grams } \\ \text { Peptone } & 5{ }^{\prime \prime} \\ \text { Carbohydrate (lactose) } & 5 \mathrm{n}\end{array}$

To the required quantity of distilled water is added the beef extract and peptone. These are dissolved by heating 
slowly on a water bath to $65^{\circ} \mathrm{C}$ and stirring until dissolved. After dissolving, the $\mathrm{pH}$ of the solution is adjusted to 7.0 . The solution is then brought to a boil. Water is added to make up the weight lost by boiling. The sugar is then added and dissolved, and the solution is filtered through paper until clear. It is then dispensed in $10 \mathrm{cc}$ amounts in the Durham fermentation tubes and sterilized in the autoclave at about 15 pounds of presure for 15 minutes.

After cooling, the tubes were inoculated with $1 \mathrm{cc}$ of water containing a $4 \mathrm{~mm}$ loop of Bacterium coli per $1000 \mathrm{cc}$ of water. The tubes were then placed in the incubator $\left(37^{\circ} \mathrm{C}\right)$ for 24 hours. At the end of this time the gas formed in the inverted vial was measured in millimeters. Then the tubes were placed in the incubator and read again at the end of 48 hours.

The readings of the amount of gas formed (in millimeters) was divided by the length of the inverted vial to give the percentage of gas formed. This was then charted.

A series of eight different groups was examined. The first group contained 14 of each of the 7 various sizes of inverted tubes, the second and third had 16, the fourth and fifth had 12, and the sixth, seventh, and elghth had 20 of each size of inverted vial. This made a total of 130 of each of the various sizes or a total of 910 tubes in all.

Following are the cinarts (Numbers 1 to 8 ) showing the measurements of gas in millimeters and the percentage of gas 
for each group. Also, there is a chart giving the average percentage for each size of tube in each chart. 
OBSERVATIONS AND DISCUSSION 
Charts in Millimeters 


\section{Ohart \#1}

size of inverted vial measured in mm
Measurement of gas (in mm) produced by Bacterium coll in the inverted vial at the end of 24 hours incubation at $37^{\circ} \mathrm{c}$.

$$
\begin{aligned}
& 9 \times 40 \\
& 7 \times 40 \\
& 5 \times 60 \\
& 5 \times 40 \\
& 5 \times 30 \\
& 7 \times 45 \\
& 9 \times 76
\end{aligned}
$$

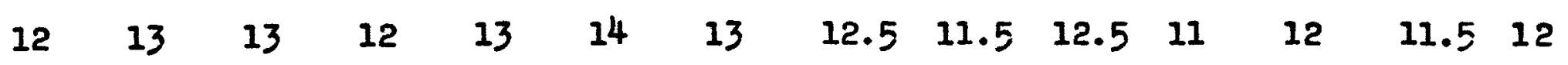

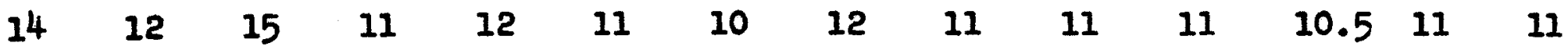

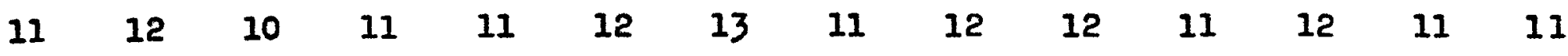

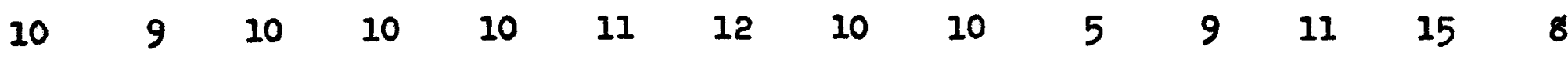

$$
\begin{aligned}
& \begin{array}{llllllllllllll}
5 & 5 & 5 & 5 & 10 & 8 & 15 & 7 & 7 & 5 & 5 & 5 & 7 & 5
\end{array}
\end{aligned}
$$

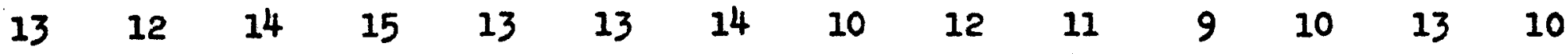

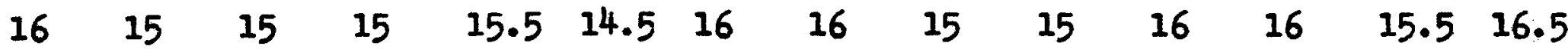

$$
\begin{aligned}
& 9 \times 40 \\
& 7 \times 40 \\
& 5 \times 60 \\
& 5 \times 40 \\
& 5 \times 30 \\
& 7 \times 45 \\
& 9 \times 76
\end{aligned}
$$

$\begin{array}{llllllllllllll}14.5 & 15 & 17 & 15 & 17 & 16 & 16 & 15 & 15 & 17 & 14 & 16 & 17 & 15 \\ 15 & 15 & 20 & 13 & 13 & 14 & 13 & 13.5 & 15 & 16 & 13 & 13 & 16 & 14 \\ 16 & 16 & 15 & 18 & 16.5 & 17.5 & 17 & 17 & 15 & 15 & 15 & 17.5 & 16.5 & 13.5 \\ 12 & 11 & 13 & 18 & 16.5 & 17.5 & 17 & 13 & 12 & 12 & 13 & 14.5 & 16 & 12 \\ 12 & 11 & 13 & 18 & 13 & 16 & 15 & 10 & 10 & 8 & 8.5 & 11 & 8.5 & 8 \\ 14 & 16 & 12 & 14 & 15 & 16 & 13 & 13 & 15 & 14 & 15 & 14 & 16 & 15 \\ 21 & 23 & 22 & 22 & 20 & 23 & 21 & 25 & 22 & 22.5 & 22 & 23 & 24 & 22\end{array}$




\section{Ohart \#2}

Bize of inverted vial mossured in $\mathrm{mm}$
Measurement of gas (in mm) produced by Baoterium coll in the inverted vial at the end of 24 hours incubation at $37^{\circ} \mathrm{c}$.
$9 \times 40$

$7 \times 40$

$5 \times 60$

$5 \times 30$

$5 \times 40$

$7 \times 45$

$9 \times 76$

$9 \times 40$

$7 \times 40$

$5 \times 60$

$5 \times 40$

$5 \times 30$

$7 \times 45$

$9 \times 76$
11.510

910

10

7

1513

1010

$\begin{array}{lllll}13 & 11.5 & 14 & 12 & 10\end{array}$

Measurement of gas (in mm) produced by Bacterium coll in the inverted vial at the end of 48 hours incubation at $37^{\circ} \mathrm{C}$.

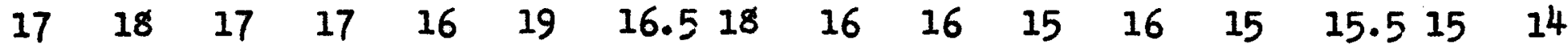



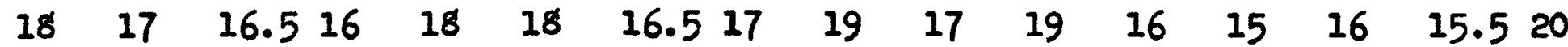

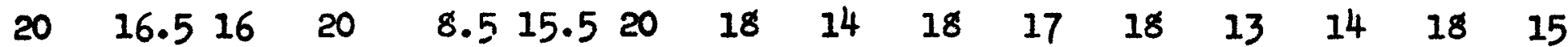

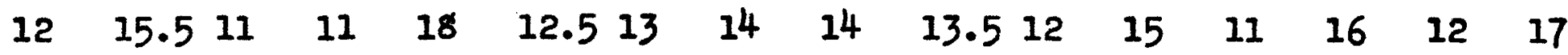

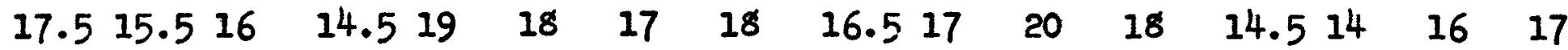
$\begin{array}{llllllllllllllll}25 & 20 & 23 & 20 & 19 & 21 & 25 & 21 & 26 & 21 & 23 & 25 & 21 & 18 & 20 & 20\end{array}$ 


\section{Chart \#3}

Size of inverted vial measured in $\mathrm{mm}$
Measurement of gas (in $\mathrm{mm}$ ) produced by Baoterium coli in the inverted vial at the end of 24 hours inoubation at $37^{\circ} 0$.

\begin{tabular}{|c|c|c|c|c|c|c|c|c|c|c|c|c|c|c|c|c|}
\hline $9 \times 40$ & 12 & 11 & 11.5 & 10 & 9 & 12 & 10 & 10.5 & 11 & 12 & 10 & 11 & 10 & 11 & 10.5 & 510 \\
\hline $7 \times 40$ & 9 & 10 & 10 & 10 & 9 & 8 & 10 & 10 & 10 & 9 & 9 & 10 & 10.5 & $5 \quad 9.5$ & 10 & 10 \\
\hline $5 \times 60$ & 10 & 10 & 10.5 & 11 & 11 & 11.5 & 10.5 & 10 & 15 & 11 & 10 & 12 & 10 & 9 & 10 & 0 \\
\hline $5 \times 40$ & 11 & 8 & 9 & 9 & 10 & 10 & 11 & 10 & 5 & 8 & 11 & 9 & 9 & 10 & 10 & \\
\hline $5 \times 30$ & 7 & 8 & 6.5 & 10 & 5 & 5 & 10 & 6 & 5 & 5 & 6.5 & 10 & 7 & 4 & 7 & \\
\hline $9 \times 76$ & 15 & 11 & 12 & 10 & 13 & 12 & 12 & 11. & 13.5 & 11 & 12 & 12 & 12 & 13 & 11 & 15 \\
\hline $7 \times 45$ & 12 & 10 & 11 & 10 & 10 & 9 & 10 & 9.5 & 10 & 11 & 10 & 9.5 & 10 & 11 & 8 & 10 \\
\hline & \multicolumn{3}{|c|}{ Measurement } & \multicolumn{10}{|c|}{$\begin{array}{l}\text { of gas (in mm) produoed by Bacterium } \\
\text { at the end of } 48 \text { hours incubation at } 37^{\circ} 0 .\end{array}$} & \multicolumn{3}{|c|}{ inverted vial } \\
\hline $9 \times 40$ & 18.5 & 20 & 18 & 17 & 15.5 & 22 & 17 & 20 & 18 & 17 & 16 & 16 & 15.5 & 517 & 15 & 15 \\
\hline $7 \times 40$ & 14 & 16 & 16 & 17 & 15 & 15 & 16 & 15 & 15 & 15 & 15 & 17 & 13 & 16 & 16 & ? \\
\hline $5 \times 60$ & 19 & 18 & $17 \cdot 5$ & 18 & 20 & 18 & 19 & 19 & 18 & 19 & 22 & 18 & 16 & 17 & 18.5 & 520 \\
\hline $5 \times 40$ & 21 & 17 & 20 & 20 & 6 & 13 & 18 & 18 & 14 & 19 & 15 & 17 & 10 & 15 & 16 & 20 \\
\hline $5 \times 30$ & 13 & 14 & 12 & 12.5 & 20 & 13 & 14 & 17 & 15 & 14 & 10 & 16 & 12 & 17 & 11 & 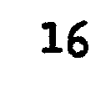 \\
\hline $9 \times 76$ & 31 & 25 & 29 & 26 & 24 & 25 & 27 & 26 & 30 & 27 & 25 & 29 & 25 & 21 & 25 & \\
\hline $7 \times 45$ & 17 & 16.5 & 17 & 15 & 20 & 20 & 18 & 18 & 18 & 18 & 20 & 20 & 15 & 18 & 18 & \\
\hline
\end{tabular}


Size of inverted vial measured in mm
Ohart 14

Measurement of gas (in mm) produced by Bacterium col1 in the inverted vial at the end of 24 hours incubation at $37^{\circ} \mathrm{c}$.

$$
\begin{aligned}
& 9 \times 40 \\
& 7 \times 40 \\
& 5 \times 60 \\
& 5 \times 40 \\
& 5 \times 30 \\
& 9 \times 76 \\
& 7 \times 45
\end{aligned}
$$

$$
\begin{aligned}
& 9 \times 40 \\
& 7 \times 40 \\
& 5 \times 60 \\
& 5 \times 40 \\
& 5 \times 30 \\
& 9 \times 76 \\
& 7 \times 45
\end{aligned}
$$

$\begin{array}{llllllllllll}11 & 11 & 10 & 12 & 11 & 10.5 & 11.5 & 11 & 12.5 & 11.5 & 11 & 11 \\ 10 & 10 & 11 & 12.5 & 11 & 11 & 11.5 & 11 & 11 & 11 & 11 & 11 \\ 11.5 & 12 & 13.5 & 11 & 11.5 & 11 & 12 & 12 & 12 & 11 & 12 & 10 \\ 10 & 10 & 10 & 10 & 7 & 12 & 11.5 & 11 & 8 & 6.5 & 10 & 6 \\ 5 & 7 & 10 & 8 & 6 & 6 & 8 & 8 & 8 & 9 & 8 & 7 \\ 12 & 13.5 & 14 & 15 & 16 & 12 & 11.5 & 13 & 15 & 13.5 & 16 & 16 \\ 12.5 & 13 & 13 & 13.5 & 14 & 13 & 12.5 & 14 & 12 & 12.5 & 11 & 12\end{array}$

Measurement of gas (in mm) produced by Bacterium ooli in the inverted vial at the end of 4 hours incubation at 379 c.

$\begin{array}{llllllllllll}17 & 18 & 17 & 18 & 18 & 17 & 17 & 17 & 17 & 17 & 17 & 16 \\ 14 & 15 & 16 & 16 & 15 & 15 & 14 & 16 & 16.5 & 16 & 17 & 15 \\ 18 & 19 & 19 & 17 & 19 & 16 & 20 & 20 & 23 & 20 & 19 & 19 \\ 19 & 15 & 15 & 16 & 12 & 15 & 15 & 16 & 13 & 16 & 17 & 12 \\ 14 & 12 & 13 & 13 & 11 & 9 & 12 & 13 & 14 & 14 & 15 & 14 \\ 21 & 22 & 21 & 20 & 23 & 20 & 22.5 & 22 & 25 & 25 & 24 & 20 \\ 19.5 & 18 & 20 & 19 & 20 & 18 & 17 & 20 & 17 & 18 & 17 & 16.5\end{array}$




\section{Chart *5}

81ze of inverted vial measured in mm
Measurement of gas (In mm) produoed by Baoterium coli in the inverted vial at the end of 24 hours incubation at $37^{\circ} \mathrm{c}$.

\begin{tabular}{|c|c|c|c|c|c|c|c|c|c|c|c|c|}
\hline $9 \times 40$ & 11.5 & 10 & 11 & 12 & 12.5 & 11 & 11 & 10.5 & 13 & 12 & 11 & \\
\hline $7 \times 40$ & 13 & 10 & 11 & 10 & 10 & 10 & 11 & 10 & 11 & 10 & 10 & 10 \\
\hline $5 \times 60$ & 10.5 & 10 & 12 & 12.5 & 10 & 12 & 11 & 10 & 12 & 12 & 11 & 12 \\
\hline $5 \times 40$ & 6.5 & 6 & 10 & 7 & 10 & 9 & 8 & 7 & 8 & 8 & 7 & .0 \\
\hline $5 \times 30$ & 5 & 6 & 8 & 6 & 6 & 7 & 7 & 5 & 5 & 8 & 5 & 7 \\
\hline $9 \times 76$ & 15 & 15 & 13 & 16 & 16 & 16 & 15 & 13 & 14 & 14 & 15 & 13 \\
\hline $7 \times 45$ & 11 & 11 & 11 & 11.5 & 11 & 12 & 12 & 13 & 11 & 11 & 10.5 & 11 \\
\hline & \multicolumn{12}{|c|}{$\begin{array}{l}\text { Measurement of gas (in mm) produced by Baoterium } \\
\text { at the end of } 48 \text { hours incubation at } 37^{\circ} \text { in the inver }\end{array}$} \\
\hline $9 \times 40$ & 22 & 18 & 15 & 16 & 15 & 16.5 & 16 & 18 & 16 & 16.5 & 16 & 75 \\
\hline $7 \times 40$ & 14 & 14 & 13 & 16 & 15 & 16 & 16 & 15 & 14 & 15 & 16 & I \\
\hline $5 \times 60$ & 18 & 18 & 15 & 18 & 16 & 16 & 18 & 18 & 17 & 17 & 16.5 & 16 \\
\hline $5 \times 40$ & 13 & 14 & 16 & 13 & 15 & 14 & 14 & 13 & 15 & 12 & 13 & \\
\hline $5 \times 30$ & 11 & 13 & 14 & 10 & 10 & 15 & 14 & 10 & 11 & 13 & 13 & \\
\hline $9 \times 76$ & 22 & 23 & 23 & 25 & 22 & 23 & 25 & 25 & 22 & 24 & 25 & \\
\hline $7 \times 45$ & 18 & 17.5 & 17 & 17 & 19 & 20 & 17 & 18 & 20 & 19 & 17 & \\
\hline
\end{tabular}




\section{Chart $\$ 6$}

Size of inverted vial measured in $\mathrm{mm}$
Weasurement of gas (In mm) produced by Baoterium
at the end of 24 hours inoubation at $\frac{\text { coli }}{37^{\circ}} \mathrm{O}$.

$\begin{array}{rrrrrrrrrrr}9 \times 40 & 8 & 9 & 9 & 9 & 9 & 9.5 & 9.5 & 9.5 & 10 & 9.5 \\ 7 \times 40 & 8 & 8 & 7 & 9.5 & 7 & 8 & 8 & 7 & 9 & 9 \\ 5 \times 60 & 8 & 9 & 9.5 & 10 & 9.5 & 10 & 9.5 & 9.5 & 11 & 9.5 \\ 5 \times 40 & 6 & 11 & 5.5 & 6 & 9 & 6 & 5.5 & 6 & 19 & 8 \\ 5 \times 30 & 3 & 6 & 3.5 & 6 & 3 & 6 & 9.5 & 3.5 & 5.5 & 11 \\ 9 \times 76 & 16 & 16 & 11 & 14 & 12.5 & 11 & 11 & 11 & 12.5 & 11 \\ 7 \times 45 & 9.5 & 10 & 9.5 & 11 & 9.5 & 10 & 9.5 & 9.5 & 11 & 9\end{array}$

Measurement of gas at the end of 24 hours (continued)

$\begin{array}{lcccccccccc}9 \times 40 & 9.5 & 9 & 9 & 9.5 & 9.5 & 10 & 9.5 & 9 & 9 & 9 \\ 7 \times 40 & 11 & 9 & 7 & 8 & 9 & 9.5 & 9 & 9 & 12 & 6 \\ 5 \times 60 & 10 & 9.5 & 11 & 11 & 10 & 9.5 & 11 & 9.5 & 10 & 9.5 \\ 5 \times 40 & 9.5 & 8 & 6 & 6 & 6 & 5.5 & 6 & 8 & 7 & 6 \\ 5 \times 30 & 4.5 & 4.5 & 4.5 & 12.5 & 4.5 & 4.5 & 3.5 & 6 & 3.5 & 3.5 \\ 9 \times 76 & 16 & 11 & 14 & 11 & 12.5 & 12.5 & 16 & 16 & 14 & 17 \\ 7 \times 45 & 10 & 9.5 & 9.5 & 10 & 9.5 & 9.5 & 11 & 9.5 & 9.5 & 11\end{array}$


Chart $\$ 6$ (continued)

Size of inverted vial measured in m
Measurement of gas (in $\mathrm{mm}$ ) produced by Bacterlum coli in the Inverted vial at the end of 48 hours inoubation at $37^{\circ} \mathrm{c}$.

$\begin{array}{lrlllllllll}9 \times 40 & 16 & 15 & 15 & 15 & 15 & 17 & 16 & 16 & 15 & 14 \\ 7 \times 40 & 15 & 14 & 15 & 15 & 16 & 15 & 16 & 15 & 14 & 16 \\ 5 \times 60 & 17 & 18 & 17 & 17 & 16 & 17 & 17 & 16 & 19 & 18 \\ 5 \times 40 & 16 & 20 & 15 & 13 & 15 & 20 & 18 & 13 & 22 & 17 \\ 5 \times 30 & 8 & 12 & 8 & 11 & 11 & 11 & 18 & 15 & 11 & 16 \\ 9 \times 76 & 24 & 25 & 29 & 24 & 23 & 24 & 21 & 23 & 29 & 26 \\ 7 \times 45 & 15 & 17 & 15 & 16 & 17 & 17 & 16.5 & 18 & 18 & 16\end{array}$

Measurement of gas at the end of 48 hours (continued)

$\begin{array}{rrrrrrrrrrr}9 \times 40 & 14 & 15 & 14 & 15 & 16 & 16 & 16 & 18 & 16 & 16 \\ 7 \times 40 & 15 & 15 & 14 & 15 & 15 & 14 & 15 & 15.5 & 15 & 16 \\ 5 \times 60 & 18 & 16 & 18 & 18 & 18 & 17 & 16 & 17 & 17 & 18 \\ 5 \times 40 & 15 & 13 & 10 & 11 & 13 & 10 & 15 & 16 & 15 & 14 \\ 5 \times 30 & 10 & 8 & 8 & 20 & 14 & 10 & 11 & 13 & 10 & 8 \\ 9 \times 76 & 28 & 25 & 26 & 24 & 20 & 25 & 24 & 23 & 22 & 25 \\ 7 \times 45 & 18 & 17 & 16 & 18 & 18 & 17 & 18 & 17 & 17 & 17\end{array}$




\section{Chart $\$ 7$}

Measurement of gas (in mm) produced by Bacterium ooli in the Inverted vial at the end of 24 hours incubation at $37^{\circ} \mathrm{c}$.

$\begin{array}{rrrrrrrrrrr}9 \times 76 & 14 & 16 & 15 & 15 & 18 & 16 & 15 & 15 & 14 & 16 \\ 5 \times 60 & 11 & 10 & 11 & 11 & 12 & 13 & 11 & 11 & 12 & 12 \\ 5 \times 40 & 7 & 6 & 7 & 9 & 6 & 8 & 6 & 7 & 8 & 9 \\ 5 \times 30 & 5 & 7 & 2 & 4 & 5 & 5 & 6 & 5 & 5 & 6 \\ 9 \times 40 & 11 & 10 & 11 & 11 & 11 & 10 & 10 & 11 & 11 & 10 \\ 7 \times 40 & 10 & 10 & 9 & 10 & 10 & 10 & 9 & 10 & 10 & 10 \\ 7 \times 45 & 11 & 12 & 11 & 12 & 10 & 12 & 11 & 12 & 11 & 11\end{array}$

Measurement of gas at the end of 24 hours (continued)

$\begin{array}{rrrrrrrrrrr}9 \times 76 & 12 & 10 & 15 & 13 & 15 & 13 & 12 & 14 & 15 & 16 \\ 5 \times 60 & 11 & 11 & 11 & 12 & 11 & 15 & 12 & 12 & 11 & 10 \\ 5 \times 40 & 8 & 9 & 10 & 10 & 8 & 15 & 8 & 10 & 11 & 10 \\ 5 \times 30 & 4.5 & 6 & 6 & 4 & 15 & 15 & 5 & 10 & 5 & 5 \\ 9 \times 40 & 11 & 11 & 11 & 12 & 11 & 11 & 11 & 12 & 10 & 10 \\ 7 \times 40 & 10 & 10 & 10 & 10 & 11 & 10 & 11 & 10 & 11 & 10 \\ 7 \times 45 & 12 & 12 & 11 & 12 & 12 & 15 & 11 & 12 & 11 & 11\end{array}$


Chart *7 (continued)

Measurement of gas (in mm) produced by Bacterium coli in the inverted vial at the end of 48 hours incubation at $37^{\circ} \mathrm{c}$.

$\begin{array}{lllllllllll}9 \times 76 & 26 & 24 & 24 & 26 & 21 & 25 & 27 & 20 & 30 & 26 \\ 5 \times 60 & 19 & 18 & 20 & 19 & 19 & 20 & 19 & 22 & 19 & 20 \\ 5 \times 40 & 13 & 13 & 14 & 18 & 14 & 18 & 20 & 13 & 18 & 18 \\ 5 \times 30 & 13 & 11 & 13 & 9 & 20 & 11 & 12 & 11 & 11 & 18 \\ 9 \times 40 & 17 & 18 & 17 & 17 & 15 & 17 & 18 & 18 & 18 & 16 \\ 7 \times 40 & 16 & 16 & 16.5 & 16 & 15 & 16 & 15 & 16 & 17 & 16 \\ 7 \times 45 & 21 & 17 & 18 & 17 & 17 & 18 & 17 & 17 & 18 & 18\end{array}$

Measurement of gas at the end of 48 hours (continued)

$\begin{array}{lllllllllll}9 \times 76 & 27 & 26 & 19 & 24 & 25 & 21 & 25 & 25 & 21 & 20 \\ 5 \times 60 & 21 & 20 & 22 & 17 & 17 & 17 & 19 & 18 & 18 & 20 \\ 5 \times 40 & 19 & 15 & 18 & 20 & 15 & 17 & 14 & 16 & 18 & 14 \\ 5 \times 30 & 17 & 11 & 18 & 21 & 11 & 14 & 11 & 22 & 13 & 16 \\ 9 \times 40 & 18 & 18 & 17.5 & 18 & 18 & 17 & 17 & 18 & 17 & 17 \\ 7 \times 40 & 15 & 16 & 16 & 20 & 15 & 15 & 17 & 15 & 17 & 17 \\ 7 \times 45 & 20 & 18 & 19 & 18 & 18 & 20 & 17 & 19 & 17 & 18\end{array}$




\section{Ohart $"=8$}

8ize of inverted vial measured in $\mathrm{mm}$
Measurement of gas (in mm) produced by Beoterium ooli in the inverted vial at the end of 24 hours incubation at $37^{\circ} \mathrm{o}$.

$\begin{array}{rrrrrrrrrrr}9 \times 40 & 11 & 10 & 11 & 10 & 11 & 12 & 11 & 11 & 10 & 10 \\ 7 \times 40 & 11 & 9 & 10 & 11 & 10 & 10 & 11 & 10 & 9 & 10 \\ 5 \times 60 & 11 & 11 & 10 & 11 & 10 & 10 & 11 & 10 & 12 & 11 \\ 5 \times 40 & 7 & 7 & 8 & 7 & 6 & 11 & 6 & 14 & 6 & 6 \\ 5 \times 30 & 9 & 8 & 9 & 5 & 1 & 5 & 10 & 6 & 5 & 5 \\ 9 \times 76 & 14 & 14 & 15 & 13 & 17 & 18 & 15 & 14 & 15 & 14 \\ 7 \times 45 & 11 & 12 & 11 & 12 & 11 & 11 & 12 & 11 & 11 & 12\end{array}$

Measurement of gas at the end of 24 hours (oontinued)

$\begin{array}{rrrrrrrrrrr}9 \times 40 & 10.5 & 10 & 11 & 10 & 12 & 11 & 11 & 12 & 11 & 12 \\ 7 \times 40 & 11 & 9 & 9 & 10 & 9 & 6 & 10 & 10 & 11 & 10 \\ 5 \times 60 & 12 & 10 & 11 & 12 & 10 & 11 & 11 & 12 & 11 & 11 \\ 5 \times 40 & 10 & 6 & 6 & 6 & 7 & 10 & 7 & 8 & 7 & 6 \\ 5 \times 30 & 3 & 8 & 7 & 4 & 4 & 5 & 6 & 4 & 6 & 6 \\ 9 \times 76 & 15 & 14 & 13 & 14 & 13 & 15 & 14 & 14 & 13 & 15 \\ 7 \times 45 & 11 & 12 & 12 & 12 & 11 & 11 & 11 & 12 & 12 & 11\end{array}$


Chart \#8 (continued)

Size of inverted vial measured in mm
Measurement of gas (in mm) produced by Bacterium ooli in the inverted vial at the end of 48 hours inoubation at $37^{\circ} \mathrm{C}$.

$\begin{array}{lllllllllll}9 \times 40 & 19 & 16 & 18 & 16 & 16 & 16 & 20 & 17 & 16 & 17 \\ 7 \times 40 & 15 & 15 & 13 & 16 & 15 & 16 & 15 & 15 & 13 & 14 \\ 5 \times 60 & 19 & 20 & 20 & 19 & 15 & 17 & 19 & 17 & 19 & 16 \\ 5 \times 40 & 13 & 11 & 13 & 17 & 15 & 17 & 20 & 15 & 15 & 13 \\ 5 \times 30 & 14 & 10 & 13 & 9 & 10 & 7 & 15 & 15 & 9 & 13 \\ 9 \times 76 & 22 & 23 & 22 & 26 & 25 & 26 & 25 & 26 & 22 & 21 \\ 7 \times 45 & 17 & 19 & 17 & 19 & 18 & 17 & 18 & 18 & 17 & 18\end{array}$

Measurement of gas at the end of 48 hours (continued)

$\begin{array}{lllllllllll}9 \times 40 & 17 & 16 & 16 & 17 & 17 & 16 & 17 & 18 & 17 & 17 \\ 7 \times 40 & 15 & 15 & 14 & 15 & 15 & 12 & 14 & 15 & 15 & 16 \\ 5 \times 60 & 18 & 18 & 18 & 18 & 16 & 17 & 17 & 20 & 18 & 19 \\ 5 \times 40 & 15 & 15 & 13 & 13 & 18 & 15 & 20 & 18 & 12 & 12 \\ 5 \times 30 & 10 & 12 & 10 & 9 & 10 & 15 & 14 & 10 & 11 & 12 \\ 9 \times 76 & 22 & 22 & 21 & 23 & 21 & 20 & 26 & 21 & 24 & 23 \\ 7 \times 45 & 18 & 16 & 16 & 17 & 17 & 16 & 18 & 18 & 17 & 18\end{array}$


Charts in Percentages 
Size of inverted vial measured in $\mathrm{mm}$

\section{- Chart "1}

Percentage of 80.8 produced by Bacterium coll in the inverted vial at the end of 24 hours incubation at $37^{\circ} \mathrm{C}$.
$9 \times 40$

$7 \times 40$

$5 \times 60$

$5 \times 40$

$5 \times 30$

$7 \times 45$

$9 \times 76$

$9 \times 40$

$7 \times 40$

$5 \times 60$

$5 \times 40$

$5 \times 30$

$9 \times 76$

$7 \times 45$

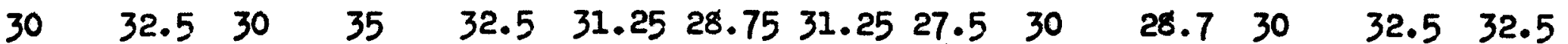

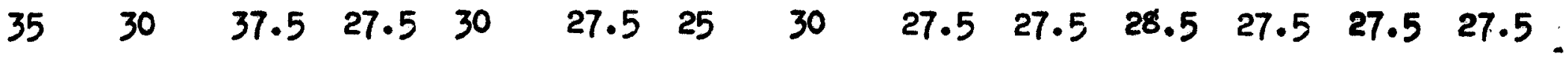

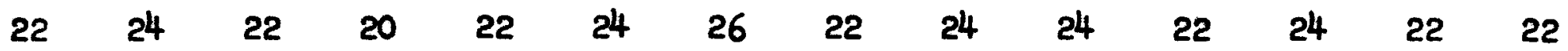

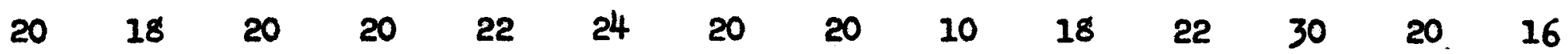

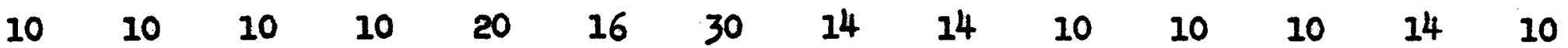

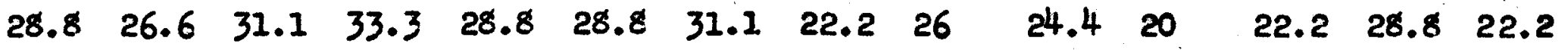

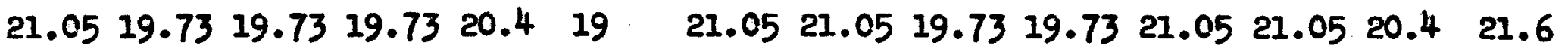

Peroentage of gas produoed by Baoterium coli in the inverted vial at the end of 48 hours inoubation at $37^{\circ} \mathrm{C}$.

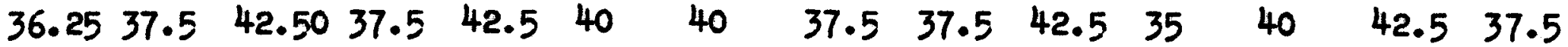

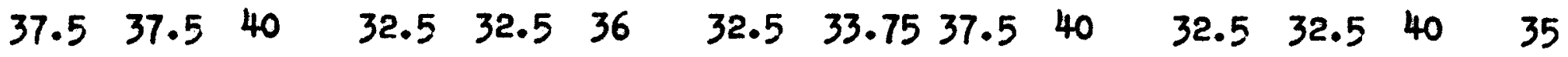

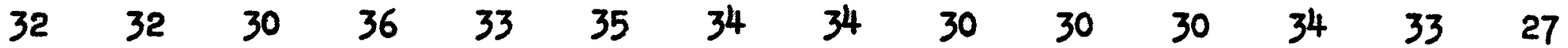



$\begin{array}{llllllllllllll}16 & 16 & 20 & 16 & 20 & 30 & 30 & 20 & 20 & 16 & 17 & 16 & 22 & 17\end{array}$

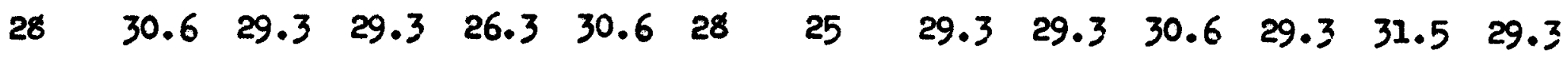

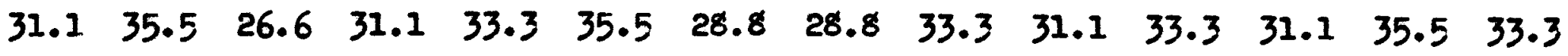


Size of inverted vial measured in $\mathrm{mm}$
Chart *2

Percentage of gas produced by Bacterium coll in the fnverted vial at the end of 24 hours Inoubation at $37^{\circ} \mathrm{o}$.






\section{Ohart \#3}

Size of inverted vial neasured in $\mathrm{mm}$
Peroentage of gas produced by Baoterium oli in the inverted vial at the end of 24 hours inoubation at $37^{\circ} \mathrm{o}$.

\begin{tabular}{|c|c|c|c|c|c|c|c|c|c|c|c|c|c|c|c|c|}
\hline $9 \times 40$ & 30 & 27.5 & 27.8 & 25 & 22.5 & 30 & 25 & 25.1 & 27.5 & 30 & 25 & 27.5 & 25 & 27.5 & 25.1 & 25 \\
\hline $7 \times 40$ & 22.5 & 25 & 25 & 25 & 22.5 & 20 & 25 & 25 & 25 & 22.5 & 22.5 & 25 & 25.1 & 23.7 & 25 & 25 \\
\hline $5 \times 60$ & 20 & 20 & 21 & 22 & 22 & 23 & 21 & 20 & 30 & 22 & 20 & 24 & 20 & 16 & 20 & 20 \\
\hline $5 \times 40$ & 22 & 16 & 18 & 18 & 20 & 20 & 22 & 20 & 10 & 16 & 22 & 18 & 18 & 20 & 20 & 12 \\
\hline $5 \times 30$ & 14 & 16 & 13 & 20 & 10 & 10 & 20 & 12 & 10 & 10 & 13 & 20 & 14 & 8 & 14 & 14 \\
\hline $9 \times 76$ & 19.73 & 14.47 & 15.98 & 13.51 & 17.10 & 15.98 & 15.98 & 14.47 & 17.7 & 14.47 & 15.98 & 16.4 & 15.98 & 17.10 & 14.47 & 1983 \\
\hline $7 \times 45$ & 26.6 & 22.2 & 24.4 & 22.2 & 22.2 & 20 & 22.2 & 21.1 & 22.2 & 24.4 & 22.2 & 21.1 & 22.2 & 24.4 & 17.7 & 222 \\
\hline & & & & Perc & & & & & $\frac{1}{n}$ & & & 30 & & & & \\
\hline$\times 40$ & 46.25 & 50 & 45 & 42.5 & 38.75 & 55 & 42.5 & 50 & 45 & 42.5 & 40 & 40 & 38.75 & 42.5 & 37.5 & 37.5 \\
\hline $7 \times 40$ & 35 & 40 & 40 & 42.5 & 37.5 & 37.5 & 40 & 37.5 & 37.5 & 37.5 & 37.5 & 42.5 & 32.5 & 40 & 40 & 32.5 \\
\hline $5 \times 60$ & 38 & 36 & 35 & 36 & 40 & 36 & 34 & 38 & 36 & 38 & 44 & 36 & 32 & 34 & 33 & 40 \\
\hline $5 \times 40$ & 42 & 34 & 40 & 40 & 12 & 26 & 36 & 36 & 34 & 38 & 30 & 34 & 20 & 30 & 32 & 30 \\
\hline$\times 30$ & 26 & 28 & 22 & 25 & 40 & 26 & 28 & 34 & 30 & 28 & 20 & 22 & 24 & 34 & 32 & 32 \\
\hline$\times 76$ & 41.89 & 32.89 & 38.1 & 34.4 & 31.57 & 32.89 & 34.21 & 39.47 & 35.52 & 32.89 & 38.15 & 32.89 & 37.62 & 32.89 & 32.89 & .5 \\
\hline $7 \times 45$ & 37.7 & 36.6 & 37.7 & 33.3 & 44.4 & 44.4 & 40 & 40 & 40 & 44.4 & 44.4 & 33.3 & 40 & 40 & 40 & 40 \\
\hline
\end{tabular}


Size of inverted rial measured in mm

\section{Chart $\$ 4$}

Percentage of gas produced by Bacterium coll in the inverted vial at the end of 24 hours incubation at $37^{\circ} \mathrm{o}$.

\begin{tabular}{|c|c|c|c|c|c|c|c|c|c|c|c|c|}
\hline $9 \times 40$ & 28.5 & 27.5 & 27.5 & 30 & 28.5 & 27.5 & 28.75 & 27.5 & 31.25 & 28.75 & 31.25 & 28.5 \\
\hline $7 \times 40$ & 25 & 25 & $27 \cdot 5$ & 31.25 & 27.5 & 27.5 & 28.75 & 27.5 & 27.5 & 27.5 & 27.5 & 27.5 \\
\hline $5 \times 60$ & 23 & 24 & 27 & 22 & 23 & 22 & 24 & 24 & 24 & 22 & 24 & 20 \\
\hline $5 \times 40$ & 20 & 20 & 20 & 20 & 14 & 24 & 23 & 22 & 16 & 15 & 20 & 12 \\
\hline $5 \times 30$ & 16 & 10 & 14 & 20 & 16 & 12 & 12 & 16 & 16 & 18 & 16 & 15 \\
\hline $9 \times 76$ & 15.87 & 17.75 & 18.42 & 19.73 & 21.05 & 15.78 & 15.13 & 17.1 & 19.73 & 17.75 & 21.05 & 21.05 \\
\hline $7 \times 45$ & 27.7 & 27.7 & 27.7 & 30 & 33.3 & 28.8 & 27.7 & 33.3 & 26.6 & 27.7 & 24.4 & 26.6 \\
\hline \multicolumn{13}{|c|}{$\begin{array}{c}\text { Percentage of gas produced by Bacterium ool1 in the inverted vial } \\
\text { at the end of } 48 \text { hours inoubation at } 37^{\circ} \mathrm{C} \text {. }\end{array}$} \\
\hline $9 \times 40$ & 42.5 & 45 & 42.5 & 45 & 45 & 42.5 & 42.5 & 42.5 & 42.5 & 42.5 & 42.5 & 40 \\
\hline $7 \times 40$ & 35 & 37.25 & 40 & 40 & 37.25 & 37.25 & 35 & 40 & 41.25 & 40 & 42.5 & 37.25 \\
\hline $5 \times 60$ & 36 & 38 & 38 & 35 & 38 & 32 & 40 & 40 & 46 & 40 & 38 & 38 \\
\hline $5 \times 40$ & 38 & 30 & 30 & 32 & 24 & 30 & 30 & 32 & 26 & 32 & 34 & 32 \\
\hline $5 \times 30$ & 28 & 24 & 26 & 26 & 22 & 18 & 24 & 26 & 28 & 28 & 30 & 28 \\
\hline $9 \times 76$ & 27.63 & 28.9 & 27.63 & 26.31 & 26.31 & 31.58 & 26.31 & 29.6 & 28.9 & 32.89 & 32.89 & 31.57 \\
\hline $7 \times 45$ & 44.4 & 43.3 & 40 & 42.2 & 44.4 & 40 & 37.7 & 44.4 & 37.7 & 40 & 37.7 & 36.6 \\
\hline
\end{tabular}


Size of inverted vial measured in $\mathrm{mm}$
Ohart $\# 5$

Percentage of gas produced by Baoterlum coll in the inverted vial at the end of 24 hours Incubat ion at $37^{\circ} \mathrm{o}$.

\begin{tabular}{|c|c|c|c|c|c|c|c|c|c|c|c|c|}
\hline $9 \times 40$ & 28.75 & 25 & 27.5 & 30 & 31.25 & $27 \cdot 5$ & 27.5 & 26.25 & 32.5 & 30 & 27.5 & 28.75 \\
\hline $7 \times 40$ & 32.5 & 25 & 27.5 & 25 & 25 & 25 & 27.5 & 25 & 27.5 & 25 & 25 & 25 \\
\hline $5 \times 60$ & 21 & 20 & 24 & 25 & 20 & 24 & 22 & 20 & 24 & 24 & 22 & 24 \\
\hline $5 \times 40$ & 13 & 12 & 20 & 14 & 20 & 18 & 18 & 14 & 16 & 16 & 14 & 20 \\
\hline $5 \times 30$ & 10 & 12 & 13 & 12 & 12 & 14 & 14 & 10 & 10 & 18 & 10 & 14 \\
\hline $9 \times 76$ & 19.75 & 19.75 & 17.1 & 21.05 & 21.05 & 21.05 & 19.73 & 17.1 & 18.42 & 18.42 & 19.73 & 17.1 \\
\hline \multirow[t]{2}{*}{$7 \times 45$} & 24.4 & 24.4 & 24.4 & 25.5 & 24.4 & 26.6 & 26.6 & 28.8 & 24.4 & 24.4 & 23.3 & 24.4 \\
\hline & & \multicolumn{11}{|c|}{$\begin{array}{c}\text { Peroentage of gas produoed by Baoterium ooll in the inverted vial } \\
\text { at the end of } 48 \text { hours inoubation at } 37^{\circ} \mathrm{c} \text {. }\end{array}$} \\
\hline $9 \times 40$ & 55 & 45 & 37.5 & 40 & 37.5 & 40 & 41.25 & 40 & 45 & 40 & 41.25 & 37.5 \\
\hline $7 \times 40$ & 35 & 35 & 32.5 & 40 & 37.5 & 40 & 40 & 37.5 & 35 & 37.5 & 40 & 37.5 \\
\hline $5 \times 60$ & 36 & 36 & 30 & 36 & 32 & 32 & 36 & 36 & 34 & 33 & 34 & 32 \\
\hline $5 \times 40$ & 26 & 28 & 32 & 26 & 30 & 28 & 28 & 26 & 30 & 26 & 24 & 24 \\
\hline $5 \times 30$ & 22 & 26 & 28 & 20 & 20 & 30 & 26 & 20 & 22 & 26 & 26 & 20 \\
\hline $9 \times 76$ & 28.9 & 31.58 & 31.58 & 32.89 & 28.9 & 31.58 & 32.89 & 32.89 & 28.9 & 31.59 & 32.89 & 26.31 \\
\hline $7 \times 45$ & 40 & 38.8 & 37.7 & 37.7 & 42.2 & 44.4 & 37.7 & 40 & 42.2 & 44.4 & 37.7 & 40 \\
\hline
\end{tabular}


8120 of inverted vial measured in $\mathrm{mm}$

\section{Ohart 46}

Percentage of gas produced by Baoterium ooll in the inverted vial at the end of 24 hours inoubat ion at $37^{\circ} \mathrm{o}$.

$$
\begin{aligned}
& 9 \times 40 \\
& 7 \times 40 \\
& 5 \times 60 \\
& 5 \times 40 \\
& 5 \times 30 \\
& 9 \times 76 \\
& 7 \times 45
\end{aligned}
$$

$$
\begin{aligned}
& 9 \times 40 \\
& 7 \times 40 \\
& 5 \times 60 \\
& 5 \times 40 \\
& 5 \times 30 \\
& 9 \times 76 \\
& 7 \times 45
\end{aligned}
$$

$\begin{array}{llllllllll}20 & 22.5 & 22.5 & 22.5 & 22.5 & 23.75 & 23.75 & 23.75 & 25 & 23.75 \\ 20 & 20 & 17.5 & 23.75 & 17.5 & 20 & 20 & 17.5 & 22.5 & 22.5 \\ 16 & 18 & 19 & 20 & 19 & 20 & 19 & 19 & 22 & 19 \\ 12 & 22 & 11 & 12 & 18 & 12 & 11 & 12 & 38 & 16 \\ 6 & 12 & 7 & 12 & 6 & 12 & 19 & 7 & 11 & 22 \\ 21.1 & 21.1 & 14.47 & 18.4 & 16.4 & 14.47 & 14.47 & 14.47 & 16.4 & 14.47 \\ 21.1 & 22.2 & 21.1 & 24.4 & 21.1 & 22.2 & 21.1 & 21.1 & 24.4 & 21.1 \\ & \text { Percentage or gas produced at the end of 24 hours (oontinued) } & \\ 22.5 & 22.5 & 23.75 & 23.75 & 25 & 23.75 & 23.7 & 22.5 & 22.5 & 22.5 \\ 27.5 & 22.5 & 17.5 & 20 & 22.5 & 23.75 & 22.5 & 22.5 & 30 & 15 \\ 20 & 19 & 22 & 22 & 20 & 19 & 22 & 19 & 20 & 19 \\ 19 & 16 & 12 & 12 & 12 & 11 & 12 & 16 & 14 & 12 \\ 9 & 9 & 9 & 25 & 9 & 9 & 7 & 12 & 7 & 7 \\ 21.1 & 14.47 & 18.4 & 14.47 & 16.4 & 16.4 & 21.1 & 21.1 & 18.4 & 22.3 \\ 22.2 & 21.1 & 21.1 & 22.2 & 21.1 & 21.1 & 24.4 & 21.1 & 21.1 & 24.4\end{array}$


Ohart \#6 (oont inued)

Size of
inverted vial measured in mm
Peroentage of gas produced by Beoterium coli in the inverted vial at the end of 48 hours incubation at $37^{\circ} \mathrm{c}$.

$\begin{array}{lllllllllll}9 \times 40 & 40 & 37.5 & 37.5 & 37.5 & 37.5 & 42.5 & 40 & 40 & 37.5 & 35 \\ 7 \times 40 & 37.5 & 35 & 37.5 & 37.5 & 40 & 37.5 & 40 & 37.5 & 35 & 40 \\ 5 \times 60 & 34 & 36 & 34 & 34 & 32 & 34 & 34 & 32 & 38 & 36 \\ 5 \times 40 & 32 & 36 & 31 & 26 & 30 & 40 & 36 & 26 & 36 & 34 \\ 5 \times 30 & 16 & 24 & 16 & 22 & 22 & 22 & 36 & 30 & 22 & 31 \\ 9 \times 76 & 31.57 & 38.1 & 31.57 & 30.2 & 31.57 & 32.8 & 27.6 & 30.2 & 38.1 & 34.2 \\ 7 \times 45 & 33.3 & 37.7 & 33.3 & 35.5 & 37.7 & 37.7 & 36.6 & 40 & 40 & 35.5\end{array}$

Peroentage of gas produced at the end of 48 hours (continued)

$\begin{array}{lllllllllll}9 \times 40 & 35 & 37.5 & 35 & 37.5 & 40 & 40 & 40 & 45 & 40 & 40 \\ 7 \times 40 & 37.5 & 37.5 & 35 & 37.5 & 37.5 & 35 & 37.5 & 38.7 & 37.5 & 40 \\ 5 \times 60 & 36 & 32 & 36 & 36 & 36 & 34 & 32 & 34 & 34 & 36 \\ 5 \times 40 & 30 & 26 & 20 & 22 & 26 & 20 & 30 & 32 & 30 & 28 \\ 5 \times 30 & 20 & 16 & 16 & 40 & 18 & 20, & 22 & 26 & 20 & 16 \\ 9 \times 76 & 36.8 & 32.8 & 34.2 & 31.57 & 26.3 & 32.8 & 31.57 & 30.2 & 28.9 & 32.8 \\ 7 \times 45 & 40 & 37.7 & 35.5 & 40 & 40 & 37.7 & 40 & 37.7 & 37.7 & 37.7\end{array}$




\section{Chart \#7}

Size of inverted vial measured in $\mathrm{mm}$
Percentage of gas produced by Bacterium 0011 in the inverted vial at the end of 24 hours incubat $\frac{10{ }^{\prime}}{\text { at }} 37^{\circ} \mathrm{o}$.

$\begin{array}{lllllllllll}9 \times 40 & 27.5 & 25 & 27.5 & 27.5 & 27.5 & 25 & 25 & 27.5 & 27.5 & 25 \\ 7 \times 40 & 25 & 25 & 22.5 & 25 & 25 & 25 & 22.5 & 25 & 25 & 25 \\ 5 \times 60 & 22 & 20 & 22 & 22 & 24 & 26 & 22 & 22 & 24 & 24 \\ 5 \times 40 & 14 & 12 & 14 & 18 & 12 & 16 & 12 & 14 & 16 & 18 \\ 5 \times 30 & 10 & 14 & 4 & 8 & 10 & 10 & 12 & 10 & 10 & 12 \\ 9 \times 76 & 18.4 & 21 & 19.7 & 19.7 & 23.6 & 19.7 & 19.7 & 18.4 & 21 & 15.7 \\ 7 \times 45 & 24.4 & 26.6 & 24.4 & 26.6 & 22.2 & 26.6 & 24.4 & 26.6 & 24.4 & 24.4 \\ & & & & & & & & & 27 \\ 9 \times 40 & 27.5 & 27.5 & 27.3 & 30 & 27.5 & 27.5 & 27.5 & 30 & 27.5 & 25 \\ 7 \times 40 & 25 & 25 & 25 & 25 & 27.5 & 25 & 27.5 & 25 & 27.5 & 25 \\ 5 \times 60 & 22 & 22 & 20 & 24 & 22 & 30 & 24 & 24 & 22 & 20 \\ 5 \times 40 & 16 & 18 & 20 & 20 & 16 & 30 & 16 & 20 & 22 & 20 \\ 5 \times 30 & 9 & 12 & 12 & 8 & 30 & 30 & 10 & 20 & 10 & 10 \\ 9 \times 76 & 13.1 & 19.7 & 17.1 & 19.7 & 17.1 & 15.7 & 21 & 18.4 & 19.7 & 21 \\ 7 \times 45 & 26.6 & 26.6 & 24.4 & 26.6 & 26.6 & 33.3 & 24.4 & 26.6 & 24.4 & 24.4\end{array}$


Size of inverted vial measured in $\mathrm{mm}$

\section{Chart $\#$ (continued)}

Percentage of gas produoed by Baoterium col1 in the inverted vial at the end of $48^{\circ}$ hours incubation at $37^{\circ} 0$.

$\begin{array}{lllllllllll}9 \times 40 & 42.5 & 45 & 42.5 & 42.5 & 37.5 & 42.5 & 45 & 45 & 45 & 40 \\ 7 \times 40 & 40 & 40 & 41.2 & 40 & 37.5 & 40 & 37.5 & 40 & 42.5 & 40 \\ 5 \times 60 & 38 & 36 & 40 & 38 & 38 & 40 & 38 & 44 & 38 & 40 \\ 5 \times 30 & 26 & 18 & 26 & 18 & 40 & 22 & 24 & 22 & 22 & 36 \\ 5 \times 40 & 26 & 26 & 28 & 36 & 28 & 36 & 40 & 26 & 36 & 36 \\ 9 \times 76 & 34.2 & 31.5 & 31.5 & 34.2 & 27.6 & 32.8 & 35.5 & 39.4 & 39.4 & 34.2 \\ 7 \times 45 & 44.4 & 37.7 & 40 & 37.7 & 37.7 & 40 & 37.7 & 37.7 & 40 & 40\end{array}$

Percentage of gas produced at the end of 48 hours (continued)

$\begin{array}{lllllllllll}9 \times 40 & 45 & 45 & 43.7 & 45 & 45 & 42.5 & 42.5 & 45 & 42.5 & 42.5 \\ 7 \times 40 & 37.5 & 40 & 40 & 50 & 37.5 & 37.5 & 42.5 & 37.5 & 42.5 & 42.5 \\ 5 \times 60 & 42 & 40 & 44 & 34 & 34 & 34 & 38 & 36 & 38 & 40 \\ 5 \times 30 & 34 & 22 & 36 & 40 & 22 & 28 & 22 & 44 & 26 & 22 \\ 5 \times 40 & 38 & 30 & 36 & 40 & 30 & 32 & 28 & 32 & 36 & 28 \\ 9 \times 76 & 35.5 & 34.2 & 25 & 31.5 & 32.8 & 27.6 & 32.8 & 31.5 & 27.6 & 26.3 \\ 7 \times 45 & 44.4 & 40 & 42.2 & 40 & 40 & 44.4 & 37.7 & 42.2 & 37.7 & 40\end{array}$


Ohart \#8

Percentage of gas produoed by Bacterium col1 in the inverted vial at the end of 24 hours inoubation at $37^{8} \mathrm{c}$.

$$
\begin{aligned}
& 9 \times 40 \\
& 7 \times 40 \\
& 5 \times 60 \\
& 5 \times 40 \\
& 5 \times 30 \\
& 9 \times 76 \\
& 7 \times 45
\end{aligned}
$$

$9 \times 40$

$7 \times 40$

$5 \times 60$

$5 \times 40$

$5 \times 30$

$9 \times 76$

$7 \times 45$

$\begin{array}{llllllllll}27.5 & 25 & 27.5 & 25 & 27.5 & 30 & 27.5 & 27.5 & 25 . & 25 \\ 27.5 & 22.5 & 25 & 27.5 & 25 & 25 & 27.5 & 25 & 22.5 & 27.5 \\ 22 & 22 & 20 & 22 & 20 & 20 & 22 & 20 & 24 & 22 \\ 14 & 14 & 16 & 14 & 12 & 22 & 12 & 28 & 12 & 12 \\ 18 & 16 & 18 & 10 & 2 & 10 & 20 & 12 & 10 & 10 \\ 18.4 & 18.4 & 19.7 & 15.7 & 21.5 & 23.7 & 19.4 & 18.4 & 19.4 & 18.4 \\ 24.4 & 26.6 & 24.4 & 26.6 & 24.4 & 24.4 & 26.6 & 24.4 & 24.4 & 26.6\end{array}$

\section{Percentage of gas produced at the end of 24 hours (oontinued)}

$\begin{array}{llllllllll}26.25 & 25 & 27.5 & 25 & 30 & 27.5 & 27.5 & 30 & 27.5 & 30\end{array}$

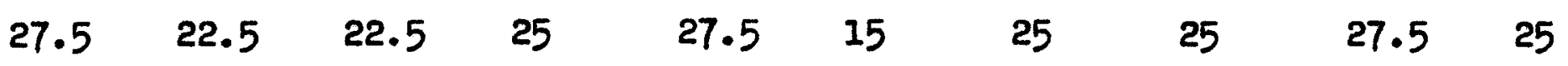

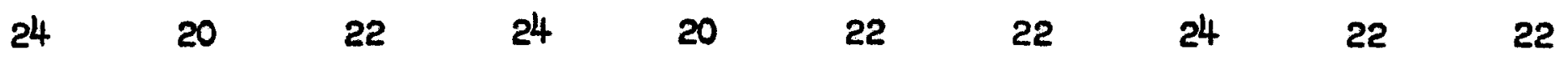

$\begin{array}{llllllllll}20 & 12 & 12 & 12 & 14 & 20 & 14 & 16 & 14 & 12\end{array}$

$\begin{array}{llllllllll}6 & 16 & 14 & 8 & 8 & 10 & 12 & 8 & 12 & 12\end{array}$

$\begin{array}{llllllllll}19.4 & 18.4 & 15.7 & 18.4 & 15.7 & 19.4 & 18.4 & 18.4 & 15.7 & 19.4\end{array}$

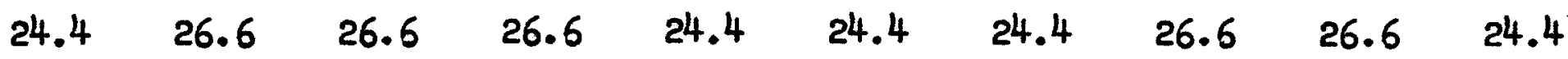


Size of inverted vial measured in mm
Chart \#8 (oontinued)

Percentage of gas produced by Baoterium coll in the inverted vial at the end of 48 hours inoubat $\frac{01}{10 n}$ at $37^{\circ} \mathrm{o}$.

$$
\begin{aligned}
& 9 \times 40 \\
& 7 \times 40 \\
& 5 \times 60 \\
& 5 \times 40 \\
& 5 \times 30 \\
& 9 \times 76 \\
& 7 \times 45
\end{aligned}
$$

$$
\begin{aligned}
& 9 \times 40 \\
& 7 \times 40 \\
& 5 \times 60 \\
& 5 \times 40 \\
& 5 \times 30 \\
& 9 \times 76 \\
& 7 \times 45
\end{aligned}
$$

$\begin{array}{llllllllll}47.5 & 40 & 45 & 40 & 40 & 40 & 50 & 42.5 & 40 & 42.5 \\ 37.5 & 37.5 & 32.5 & 40 & 37.5 & 40 & 37.5 & 37.5 & 32.5 & 35 \\ 38 & 40 & 40 & 38 & 30 & 34 & 38 & 34 & 38 & 32 \\ 26 & 22 & 26 & 32 & 30 & 32 & 40 & 30 & 30 & 26 \\ 28 & 20 & 26 & 18 & 20 & 14 & 30 & 30 & 18 & 26 \\ 28.9 & 31.5 & 28.9 & 34.2 & 32.8 & 34.2 & 32.8 & 34.2 & 28.9 & 27.8 \\ 37.7 & 42.2 & 37.7 & 42.2 & 40 & 37.7 & 40 & 40 & 37.7 & 40\end{array}$

Peroentage of gas produced at the end of 48 hours (continued)

$\begin{array}{llllllllll}42.5 & 40 & 40 & 42.5 & 42.5 & 40 & 42.5 & 45 & 42.5 & 42.5 \\ 37.5 & 37.5 & 35 & 37.5 & 37.5 & 30 & 35 & 37.5 & 37.5 & 40 \\ 36 & 36 & 36 & 36 & 32 & 34 & 34 & 40 & 36 & 38 \\ 30 & 30 & 26 & 26 & 36 & 30 & 40 & 36 & 24 & 24 \\ 20 & 24 & 20 & 18 & 20 & 30 & 28 & 20 & 22 & 24 \\ 28.9 & 28.9 & 27.8 & 31.5 & 27.8 & 26.3 & 27.8 & 34.2 & 33.02 & 31.5 \\ 40 & 35.5 & 35.5 & 37.7 & 37.7 & 35.5 & 40 & 40 & 37.7 & 40\end{array}$


Discussion of Charts 


\section{Chart \#1}

At the end of 24 hours incubation at $37^{\circ} \mathrm{C}$ :

1. Inner vials $9 \mathrm{~mm} \times 40 \mathrm{~mm}$ and $7 \mathrm{~mm} \times 45 \mathrm{~mm}$ indicated the highest percentages of gas.

2. Inner vials $5 \mathrm{~mm} \times 30 \mathrm{~mm}, 5 \mathrm{~mm} \times 40 \mathrm{~mm}, 9 \mathrm{~mm} \times 76 \mathrm{~mm}$ and $5 \mathrm{~mm} \times 60 \mathrm{~mm}$ indicated the lowest percentages of gas, the $5 \mathrm{~mm} \times 30 \mathrm{~mm}$ size showing the lowest percentage.

3. The highest percentage of gas, $37.5 \%$, was found in the $7 \mathrm{~mm} \times 40 \mathrm{~mm}$ size.

4. The lowest percentage, $10 \%$, was found in the $5 \mathrm{~mm} x$ $30 \mathrm{~mm}$ size.

5. The $9 \mathrm{~mm} \times 40 \mathrm{~mm}$ size had the highest percentage of gas, 9 vials out of a possible 14.

At the end of 48 hours incubation at $37^{\circ} \mathrm{C}$ :

1. The $9 \mathrm{~mm} \times 40 \mathrm{~mm}$ and the $7 \mathrm{~mm} \times 40 \mathrm{~mm}$ vials gave the highest percentage of gas formation.

2. The lowest percentage of gas was formed in the $5 \mathrm{~mm} \times 60 \mathrm{~mm}, 7 \mathrm{~mm} \times 45 \mathrm{~mm}, 9 \mathrm{~mm} \times 76 \mathrm{~mm}, 5 \mathrm{~mm} \times 40 \mathrm{~mm}$ and $5 \mathrm{~mm} \times 30 \mathrm{~mm}$ vials.

3. The highest percentage of gas formed was $42.5 \%$-in the $9 \mathrm{~mm} \times 40 \mathrm{~mm}$ size.

4. The lowest was $16 \%$ - in the $5 \mathrm{~mm} \times 30 \mathrm{~mm}$ size.

5. The $9 \mathrm{~mm} \times 40 \mathrm{~mm}$ size had the highest percentage of gas, 11 out of the 14 tubes used.

Conclusion: For total efficiency the $9 \mathrm{~mm} \times 40 \mathrm{~mm}$ size was the most efficient. The $5 \mathrm{~mm} \times 30 \mathrm{~mm}$ size ranked the lowest and was therefore the least efficient. 


\section{Chart \#2}

At the end of 24 hours incubation at $37^{\circ} \mathrm{C}$ :

1. The lowest percentage of gas was formed in the vials $5 \mathrm{~mm} \times 30 \mathrm{~mm}, 5 \mathrm{~mm} \times 40 \mathrm{~mm}, 9 \mathrm{~mm} \times 76 \mathrm{~mm}$, and $5 \mathrm{~mm} \times 60 \mathrm{~mm}$. Of these the lowest percentage of gas was in the $5 \mathrm{~mm} \times 30 \mathrm{~mm}$ size.

2. The highest percentage of gas was found in vials $9 \mathrm{~mm} \times 40 \mathrm{~mm}, 7 \mathrm{~mm} \times 40 \mathrm{~mm}$, and $7 \mathrm{~mm} \times 45 \mathrm{~mm}$.

3. The highest percentage of $28.75 \%$ was collected in the $9 \mathrm{~mm} \times 40 \mathrm{~mm}$ size.

4. The lowest percentage, 10\%, was found in the $5 \mathrm{~mm} \times 30 \mathrm{~mm}$ size.

5. The $9 \mathrm{~mm} \times 40 \mathrm{~mm}$ size had the highest percentage of gas in 14 out of 16 trials.

At the end of 48 hours incubation at $37^{\circ} \mathrm{C}$ :

1. The highest percentages of gas were shown in the inner vials $9 \mathrm{~mm} \times 40 \mathrm{~mm}, 7 \mathrm{~mm} \times 40 \mathrm{~mm}$, and $7 \mathrm{~mm} \times 45 \mathrm{~mm}$.

2. The lowest percentages were shown in the $5 \mathrm{~mm} \times 30 \mathrm{~mm}$, $5 \mathrm{~mm} \times 40 \mathrm{~mm}, 9 \mathrm{~mm} \times 76 \mathrm{~mm}$, and $5 \mathrm{~mm} \times 60 \mathrm{~mm}$.

3. The highest percentage, $47.5 \%$, was found in the $9 \mathrm{~mm} \times 40 \mathrm{~mm}$ size.

4. The lowest percentage, $22 \%$, was found in the $5 \mathrm{~mm} \times 30 \mathrm{~mm}$ size.

5. The $9 \mathrm{~mm} \times 40 \mathrm{~mm}$ size had the highest percentage of gas in 10 out of 16 trials.

Conclusion: The $9 \mathrm{~mm} \times 40 \mathrm{~mm}$ size of inner vials was the most efficient and the $5 \mathrm{~mm} \times 30 \mathrm{~mm}$ size was the least efficient in collecting gas. 


\section{Chart \#3}

At the end of 24 hours incubation at $37^{\circ} \mathrm{C}$ :

1. The vials with the lowest percentage of gas were the $5 \mathrm{~mm} \times 30 \mathrm{~mm}, 9 \mathrm{~mm} \times 76 \mathrm{~mm}, 5 \mathrm{~mm} \times 60 \mathrm{~mm}$, and

$5 \mathrm{~mm} \times 40 \mathrm{~mm}$ vials.

2. The vials with the highest percentage of gas were the $9 \mathrm{~mm} \times 40 \mathrm{~mm}, 7 \mathrm{~mm} \times 40 \mathrm{~mm}$, and $7 \mathrm{~mm} \times 45 \mathrm{~mm}$ vials.

3. The highegt percentage of gas, $27.8 \%$, was collected in the $9 \mathrm{~mm} \times 40 \mathrm{~mm}$ size.

4. The lowest percentage of gas, $10 \%$, was collected in the $5 \mathrm{~mm} \times 30 \mathrm{~mm}$ size.

5. The $9 \mathrm{~mm} \times 40 \mathrm{~mm}$ size had the highest percentage of gas in 15 out of 16 trials.

At the end of 48 hours incubation at $37^{\circ} \mathrm{C}$ :

1. The tubes having the lowest percentage were the $5 \mathrm{~mm} \times 30 \mathrm{~mm}, 5 \mathrm{~mm} \times 40 \mathrm{~mm}, 9 \mathrm{~mm} \times 76 \mathrm{~mm}$, and $5 \mathrm{~mm} \times 60 \mathrm{~mm}$ vials.

2. The highest percentage of gas were found in the $9 \mathrm{~mm} \times 40 \mathrm{~mm}, 7 \mathrm{~mm} \times 40 \mathrm{~mm}$, and $7 \mathrm{~mm} \times 45 \mathrm{~mm}$ vials.

3. The highest percentage of gas, 55\%, was collected in the $9 \mathrm{~mm} \times 40 \mathrm{~mm}$ size.

4. The lowest percentage of gas, $12 \%$, was collected in the $5 \mathrm{~mm} \times 40 \mathrm{~mm}$ size.

5. The $9 \mathrm{~mm} \times 40 \mathrm{~mm}$ size had the highest percentage of gas in 11 out of 16 trials.

Conclusion: The $9 \mathrm{~mm} \times 40 \mathrm{~mm}$ size was the vial most efficiont and the $5 \mathrm{~mm} \times 30 \mathrm{~mm}$ size the least efficient in collection of gas. 


\section{Chart \#4}

At the end of 24 hours incubation at $37^{\circ} \mathrm{C}$ :

1. The vials with the lowest percentages of gas were the $5 \mathrm{~mm} \times 30 \mathrm{~mm}, 5 \mathrm{~mm} \times 40 \mathrm{~mm}$, and $5 \mathrm{~mm} \times 60 \mathrm{~mm}$ sizes.

2. The vials having the highest percentages of gas were the $9 \mathrm{~mm} \times 40 \mathrm{~mm}, 7 \mathrm{~mm} \times 40 \mathrm{~mm}$, and $7 \mathrm{~mm} \times 45 \mathrm{~mm}$ sizes.

3. The highest percentage of gas, $33.35 \%$, was collected in the $7 \mathrm{~mm} \times 45 \mathrm{~mm}$ size.

4. The lowest percentage of gas, $10 \%$, was collected in the $5 \mathrm{~mm} \times 30 \mathrm{~mm}$ size.

5. The $9 \mathrm{~mm} \times 40 \mathrm{~mm}$ size had the highest percentage of gas formation in 8 out of 12 trials.

At the end of 48 hours incubation at $37^{\circ} \mathrm{C}$ :

1. The vials with the lowest percentages of gas were the $5 \mathrm{~mm} \times 30 \mathrm{~mm}, 9 \mathrm{~mm} \times 76 \mathrm{~mm}, 5 \mathrm{~mm} \times 40 \mathrm{~mm}$, and

$5 \mathrm{~mm} \times 60 \mathrm{~mm}$ sizes.

2. The vials with the highest percentages of gas were the $9 \mathrm{~mm} \times 40 \mathrm{~mm}, 7 \mathrm{~mm} \times 45 \mathrm{~mm}$, and $7 \mathrm{~mm} \times 40 \mathrm{~mm}$.

3. The highest percentage of gas, $45 \%$, was collected in $9 \mathrm{~mm} \times 40 \mathrm{~mm}$ size.

4. The lowest percentage of gas, $18 \%$, was collected in the $5 \mathrm{~mm} \times 30 \mathrm{~mm}$ size.

5. The $9 \mathrm{~mm} \times 40 \mathrm{~mm}$ size had the highest percentage of gas formation in 9 out of 12 trials.

Conclusion: The $9 \mathrm{~mm} \times 40 \mathrm{~mm}$ size was the most efficient and the $5 \mathrm{~mm} \times 30 \mathrm{~mm}$ the least efficient in collecting gas. 


\section{Chart \#5}

At the end of 24 hours incubation at $37^{\circ} \mathrm{C}$ :

1. The highest percentages of gas were attained by the $9 \mathrm{~mm} \times 40 \mathrm{~mm}, 7 \mathrm{~mm} \times 40 \mathrm{~mm}$, and $7 \mathrm{~mm} \times 45 \mathrm{~mm}$ vials.

2. The lowest percentazes of gas were attained by the $5 \mathrm{~mm} \times 30 \mathrm{~mm}, 5 \mathrm{~mm} \times 40 \mathrm{~mm}, 5 \mathrm{~mm} \times 60 \mathrm{~mm}$, and $9 \mathrm{~mm} \times 76 \mathrm{~mm}$ vials.

3. The highest percentage of gas, $32.5 \%$, was collected in the $9 \mathrm{~mm} \times 40 \mathrm{~mm}$ size.

4. The lowest percentage of gas, $10 \%$, was collected in the $5 \mathrm{~mm} \times 30 \mathrm{~mm}$ size.

5. The $9 \mathrm{~mm} \times 40 \mathrm{~mm}$ size had the highest percentage of gas in 10 out of 12 trials.

At the end of 48 hours incubation at $37^{\circ} \mathrm{C}$ :

1. The highest percentages of sas were collected in the $9 \mathrm{~mm} \times 40 \mathrm{~mm}, 7 \mathrm{~mm} \times 45 \mathrm{~mm}$, and $7 \mathrm{~mm} \times 40 \mathrm{~mm}$ vials.

2. The lowest percentages of gas vere collected in the $5 \mathrm{~mm} \times 30 \mathrm{~mm}, 5 \mathrm{~mm} \times 40 \mathrm{~mm}, 9 \mathrm{~mm} \times 76 \mathrm{~mm}$, and $5 \mathrm{~mm} \times 60 \mathrm{~mm}$ vials.

3. The highest percentage of gas, 55\%, was collected in the $9 \mathrm{~mm} \times 40 \mathrm{~mm}$ size.

4. The lowest percentage of gas, $20 \%$, was collected in the $5 \mathrm{~mm} \times 30 \mathrm{~mm}$ size.

5. The $9 \mathrm{~mm} \times 40 \mathrm{~mm}$ size had the highest percentage of gas in 9 out of 12 trials.

Conclusion: The $9 \mathrm{~mm} \times 40 \mathrm{~mm}$ size was the most efficient and the $5 \mathrm{~mm} \times 30 \mathrm{~mm}$ the least efficient in collecting gas. 
Chart \#6

At the end of 24 hours incubation at $37^{\circ} \mathrm{C}$ :

1. The highest percentage of gas was formed in the vials $9 \mathrm{~mm} \times 40 \mathrm{~mm}, 7 \mathrm{~mm} \times 45 \mathrm{~mm}$, and $7 \mathrm{~mm} \times 40 \mathrm{~mm}$.

2. The lowest percentage of gas was formed in the $5 \mathrm{~mm} \times 30 \mathrm{~mm}, 5 \mathrm{~mm} \times 40 \mathrm{~mm}, 9 \mathrm{~mm} \times 76 \mathrm{~mm}$, and $5 \mathrm{~mm} \times 60 \mathrm{~mm}$ vials.

3. The highest percentage of gas, $25 \%$, was collected in the $9 \mathrm{~mm} \times 40 \mathrm{~mm}$ size.

4. The lowest percentage of gas, $6 \%$, was collected in the $5 \mathrm{~mm} \times 30 \mathrm{~mm}$ size.

5. The $9 \mathrm{~mm} \times 40 \mathrm{~mm}$ size had the highest percentage of ga.s in 16 out of 20 trials.

At the end of 48 hours incubation at $37^{\circ} \mathrm{C}$ :

1. The highest percentages of gas were found in the $9 \mathrm{~mm} \times 40 \mathrm{~mm}, 7 \mathrm{~mm} \times 40 \mathrm{~mm}$, and $7 \mathrm{~mm} \times 45 \mathrm{~mm}$ vials.

2. The lowest percentages of gas were found in the $5 \mathrm{~mm} \times 30 \mathrm{~mm}, 5 \mathrm{~mm} \times 40 \mathrm{~mm}, 9 \mathrm{~mm} \times 76 \mathrm{rm}$, and $5 \mathrm{~mm} \times 60 \mathrm{~mm}$ vials.

3. The highest percentage of gas, $45 \%$, was collected in the $9 \mathrm{~mm} \times 40 \mathrm{~mm}$ size.

4. The lowest percentage of gas, $16 \%$, was collected in the $5 \mathrm{~mm} \times 30 \mathrm{~mm}$ size.

5. The $9 \mathrm{~mm} \times 40 \mathrm{~mm}$ size had the highest percentage of gas in 10 out of 20 trials.

Conclusion: The $9 \mathrm{~mm} \times 40 \mathrm{~mm}$ size was the most efficient and the $5 \mathrm{~mm} \times 30 \mathrm{~mm}$ the least efficient in collecting gas. 
Chart \#7

At the end of 24 hours incubation at $37^{\circ} \mathrm{C}$ :

1. The vials having the highest percentage of gas formation were the $9 \mathrm{~mm} \times 40 \mathrm{~mm}, 7 \mathrm{~mm} \times 40 \mathrm{~mm}$, and $7 \mathrm{~mm} \times 45 \mathrm{~mm}$ sizes.

2. The lowest percentages of as were found in the $5 \mathrm{~mm} \times 30 \mathrm{~mm}, 5 \mathrm{~mm} \times 40 \mathrm{~mm}, 9 \mathrm{~mm} \times 76 \mathrm{~mm}$, and $5 \mathrm{~mm} \times 60 \mathrm{~mm}$ vials.

3. The highest percentage of gas, $33.3 \%$, was collected in the $7 \mathrm{~mm} \times 45 \mathrm{~mm}$ size.

4. The lowest percentage of gas, $4 \%$, was collected in the $5 \mathrm{~mm} \times 30 \mathrm{~mm}$ size.

5. The $9 \mathrm{~mm} \times 40 \mathrm{~mm}$ size attained the highest percentage of gas in 14 out of 20 trials.

At the end of 48 hours incubation at $37^{\circ} \mathrm{C}$ :

1. The vials having the lowest percentaces of gas were the $5 \mathrm{~mm} \times 30 \mathrm{~mm}, 5 \mathrm{~mm} \times 40 \mathrm{~mm}, 5 \mathrm{~mm} \times 60 \mathrm{~mm}$, and $9 \mathrm{~mm} \times 76 \mathrm{~mm}$ sizes.

2. The highest percentages of gas were found in the $9 \mathrm{~mm} \times 40 \mathrm{~mm}, 7 \mathrm{~mm} \times 45 \mathrm{~mm}$, and $7 \mathrm{~mm} \times 40 \mathrm{~mm}$ sizes.

3. The highest percentage of gas, $45.5 \%$, was collected in the $9 \mathrm{~mm} \times 40 \mathrm{~mm}$ size.

4. The lowest percentage of gas, $18 \%$, was collected in the $5 \mathrm{~mm} \times 30 \mathrm{~mm}$ size.

5. The $9 \mathrm{~mm} \times 40 \mathrm{~mm}$ size had the highest percentage of gas in 17 out of 20 trials.

Conclusion: The $9 \mathrm{~mm} \times 40 \mathrm{~mm}$ size was the most efficient and the $5 \mathrm{~mm} \times 30 \mathrm{~mm}$ the least efficient in collecting gas. 
At the end of 24 hours incubation at $37^{\circ} \mathrm{C}$ :

1. The lowest percentages of gas were found in the $5 \mathrm{~mm} \times 30 \mathrm{~mm}, 5 \mathrm{~mm} \times 40 \mathrm{~mm}, 9 \mathrm{~mm} \times 76 \mathrm{~mm}$, and $5 \mathrm{~mm} \times 60 \mathrm{~mm}$ vials.

2. The highest percentages of gas were found in the $9 \mathrm{~mm} \times 40 \mathrm{~mm}, 7 \mathrm{~mm} \times 45 \mathrm{~mm}$, and $7 \mathrm{~mm} \times 40 \mathrm{~mm}$ vials.

3. The highest percentage of $8 a s, 30 \%$, was collected in the $9 \mathrm{~mm} \times 40 \mathrm{~mm}$ size.

4. The lowest percentage of gas, $6 \%$, was collected in the $5 \mathrm{~mm} \times 30 \mathrm{~mm}$ size.

5. The $9 \mathrm{~mm} \times 40 \mathrm{~mm}$ size had the highest percentage in 13 out of 20 trials.

At the end of 48 hours incubation at $37^{\circ} \mathrm{C}$ :

1. The lowest percentages of gas were found in the $5 \mathrm{~mm} \times 30 \mathrm{~mm}, 5 \mathrm{~mm} \times 40 \mathrm{~mm}, 9 \mathrm{~mm} \times 76 \mathrm{~mm}$, and $5 \mathrm{~mm} \times 60 \mathrm{~mm}$ vials.

2. The highest percentages of gas were found in the $9 \mathrm{~mm} \times 40 \mathrm{~mm}, 7 \mathrm{~mm} \times 45 \mathrm{~mm}$, and $7 \mathrm{~mm} \times 40 \mathrm{~mm}$ vials.

3. The highest percentage of gas, $47.5 \%$, was collected in the $9 \mathrm{~mm} \times 40 \mathrm{~mm}$ size.

4. The lowest percentage of gas, $14 \%$, was collected in the $5 \mathrm{~mm} \times 30 \mathrm{~mm}$ size.

5. The $9 \mathrm{~mm} \times 40 \mathrm{~mm}$ size had the highest percentage of gas in 20 out of 20 trials.

Conclusion: The $9 \mathrm{~mm} \times 40 \mathrm{~mm}$ size was the most efficient and the $5 \mathrm{~mm} \times 30 \mathrm{~mm}$ the least efficient in collecting gas. 
Chart of Averages 
Chart of Averages

Size of inverted vial measured in $\mathrm{mm}$
Average percentage of gas produced by Bacterium coli in the Inverted vial at the end of 24 hours incubation at $37^{\circ} \mathrm{o}$.

$\begin{array}{lllllllll}9 \times 40 & 30.9 & 24.6 & 26.6 & 27.9 & 28.5 & 23.1 & 27.1 & 27.2 \\ 7 \times 40 & 29.1 & 25 & 23.9 & 27.5 & 26.2 & 21.25 & 25.1 & 24.9 \\ 5 \times 60 & 22.8 & 19.6 & 20.1 & 23.3 & 22.5 & 19.65 & 22.9 & 21.8 \\ 5 \times 40 & 20 & 17.9 & 18.3 & 18 & 16.1 & 15 & 17.2 & 15.1 \\ 5 \times 30 & 13.4 & 14.7 & 13.1 & 15.1 & 12.4 & 10.85 & 12.5 & 11.7 \\ 7 \times 45 & 26.4 & 22.8 & 22.4 & 28.6 & 25.9 & 21.9 & 25.2 & 25.3 \\ 9 \times 76 & 20.7 & 16.6 & 16.18 & 19.2 & 19.8 & 17.5 & 18.9 & 18.6\end{array}$

Average percentage of gas produced at the end of 48 hours incubation.

$9 \times 40$

$7 \times 40$

$5 \times 60$

$5 \times 40$

$5 \times 30$

$7 \times 45$

$9 \times 76$ $\begin{array}{llllllll}39.2 & 40.3 & 43.3 & 41.6 & 42.9 & 38.8 & 43.3 & 42.4\end{array}$

$\begin{array}{llllllll}35.6 & 37.9 & 38.05 & 37.2 & 38.5 & 37.5 & 40.3 & 36.6\end{array}$

$\begin{array}{llllllll}32.1 & 34.2 & 36.6 & 33.9 & 38.2 & 34.5 & 36.5 & 36\end{array}$

$\begin{array}{llllllll}27.0 & 32.7 & 32.1 & 27.3 & 28.3 & 28.5 & 32.5 & 29.8\end{array}$

$\begin{array}{llllllll}19.7 & 26.8 & 28.0 & 24 & 25.6 & 23.25 & 22.4 & 22.8\end{array}$

$\begin{array}{llllllll}32.1 & 37.25 & 39.8 & 40.56 & 40.5 & 37.5 & 40.1 & 38.7\end{array}$

$\begin{array}{llllllll}29.0 & 27.79 & 35.1 & 30.9 & 29.26 & 32.19 & 32.2 & 30.59\end{array}$ 
Discussion of Averages 
Discussion of Averages

After averaging the percentages for each size tube in each group of the series, it is evident that the $9 \mathrm{~mm} \times 40 \mathrm{~mm}$ size vial had the highest average percentage of gas formation at the end of 24 hours incubation at $37^{\circ} \mathrm{C}$. in each chart with the exception of Chart \#4 in which the $7 \mathrm{~mm} \times 45 \mathrm{~mm}$ size had an average percentage of 28.6 as compared to the average percentage of 27.9 for the $9 \mathrm{~mm} \times 40 \mathrm{~mm}$ size. At the end of 48 hours incubation the $9 \mathrm{~mm} \times 40 \mathrm{~mm}$ size had the highest percentage of gas in all charts.

The inner vials $9 \mathrm{~mm} \times 40 \mathrm{~mm}, 7 \mathrm{~mm} \times 40 \mathrm{~mm}$, and $7 \mathrm{~mm} \times 45 \mathrm{~mm}$ were the most efficient in indicating gas production according to the chart of averages. The $7 \mathrm{~mm} \times 45 \mathrm{~mm}$ size, having 4 out of 8 vials with the second highest percentage at the end of 24 hours incubation and 5 out of 8 tubes second at the end of 48 hours incubation, ranked second to the $9 \mathrm{~mm} \times 40 \mathrm{~mm}$ size. The $7 \mathrm{~mm} \times 40 \mathrm{~mm}$ size had 4 out of 8 second highest average percentages at the end of 24 hours incubation but ranked second only 3 out of 8 possible times at the end of 48 hours incubation.

The $5 \mathrm{~mm} \times 30 \mathrm{~mm}$ and $5 \mathrm{~mm} \times 40 \mathrm{~mm}$ vials had the lowest average percentages of gas formation in all groups both for 48 and 24 hour incubations. The $5 \mathrm{~mm} \times 60 \mathrm{~mm}$ and $9 \mathrm{~mm} \times 76 \mathrm{~mm}$ vials, although having lower average percentages than the $9 \mathrm{~mm} \times 40 \mathrm{~mm}, 7 \mathrm{~mm} \times 40 \mathrm{~mm}$, and $7 \mathrm{~mm} \times 45 \mathrm{~mm}$ vials, were found to be more efficient than the $5 \mathrm{~mm} \times 30 \mathrm{~mm}$ and $5 \mathrm{~mm} \times 40 \mathrm{~mm}$ vials. 
SUMMARY AND CONCLUSIONS 
The following table summarizes the number of times the $9 \mathrm{~mm} \times 40 \mathrm{~mm}$ (flat top) inverted vial attained the highest percentage of gas during 24 and 48 hours of incubation and the total number of tubes of this size used.

\section{Hours Incubation}

Group Total No. of Tubes Used No. of times $9 \mathrm{~mm} \times 40 \mathrm{~mm}$ size attained highest percent,age

Chart \#1

$$
\begin{array}{r}
7 \\
2 \\
3 \\
4 \\
5 \\
6 \\
7 \\
8
\end{array}
$$

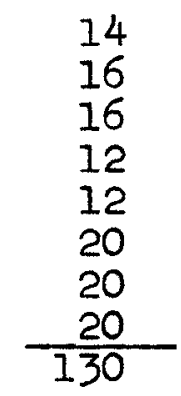

48 Hours Incubation

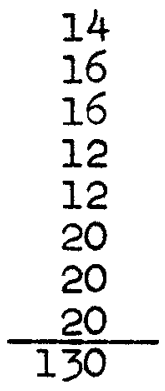

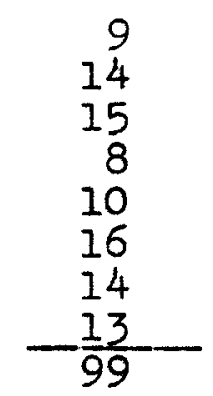

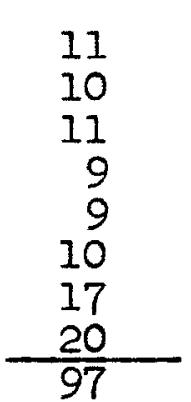

Out of 130 trials the $9 \mathrm{~mm} \times 40 \mathrm{~mm}$ size (flat top) inverted vial showed the highest percentage of gas production 99 times at the end of 24 hours incubation. At the end of 48 hours incubation the $9 \mathrm{~mm} \times 40 \mathrm{~mm}$ size (flat top) inverted vial had the highest percentage of gas 97 times.

NOTE: The decrease in the number of $9 \mathrm{~mm} \times 40 \mathrm{~mm}$ vials which obtained the highest percentage of gas production at the end of 48 hours was due to the fact that tubes of other sizes which were near the $9 \mathrm{~mm} \times 40 \mathrm{~mm}$ in gas production at the end of 24 hours replaced the $9 \times 40$ at the end of 
48 hours incubation by showing a more rapid increase in gas production, to a small extent.

\section{Conclusions}

1. On the basis of averages the $9 \mathrm{~mm} \times 40 \mathrm{~mm}$ size inverted vial was found to yield the highest percentage of gas formation after 24 hours and 48 hours incubations at $37^{\circ} \mathrm{C}$.

2. With regard to total efficiency, the $9 \mathrm{~mm} \times 40 \mathrm{~mm}$ size would rank as the most efficient. Out of 130 tubes used 99 attained the highest percentages after 24 hours incubation, and 97 had the highest percentages after 48 hours incubation.

3. The $5 \mathrm{~mm} \times 40 \mathrm{~mm}$ and $5 \mathrm{~mm} \times 30 \mathrm{~mm}$ vials were the least efficient having the lowest average percentages of gas and the lowest percentages in each group.

4. The $7 \mathrm{~mm} \times 40 \mathrm{~mm}$ and $7 \mathrm{~mm} \times 45 \mathrm{~mm}$ inverted vials although not as efficient as the $9 \times 40 \mathrm{~mm}$ size were found to be more efficient than the $5 \mathrm{~mm} \times 60 \mathrm{~mm}$ and $9 \mathrm{~mm} \times 76 \mathrm{~mm}$ inverted vials. 


\section{REFERTNCES}




\section{References}

American Public Health Association, Methods for the Examination of Water and Sewage, 8 th edition, 1936.

Browne, William: "A comparative study of the Smith fermentation tube and the inverted vial in the determination of sugar fermentation." American Journal of Public Health, 3, $701-704(1913)$.

Durham, Herbert E.: "A Simple Method for Demonstrating Gas Production by Bacteria." British Medical Journal, I, 1387 (1898).

Graves, K. D.: "An Improved Modification of the Durham Fermentation Tube." Journal of American Medical Association, 69, 2102 (1917).

Hall, I. C.: "An Improved (Durham) Fermentation Tube." American Journal of Public Health, 4, 1173-1178 (1914).

Lee, R. E. and Fegely, W. N.: "An Experimental Study of the Relative Efficiencies of Certain Fermentation Tubes." American Journal of Public Health, 4, 999 (1914).

Smith, Theobald: "The Fermentation Tube." The Wilder quarter Century Book, 1893, pp. 187-232, Comstock Publishing Co., Ithaca, New York. 